\title{
Monitoring and current research of groundwater resources and recharge in the Doñana Natural area (SE Spain)
}

\begin{abstract}
Claus Kohfahl(1), Lidia Molano-Leno(1), Carolina Guardiola(1), Marisol Manzano(2), Fernando Ruiz(1), Nuria Naranjo-Fernández ${ }^{(1)}$, Ana Rebollo ${ }^{(6)}$, Daniel Martínez $^{(1)}$, Antonio Martínez ${ }^{(1)}$, Javier Heredia ${ }^{(1)}$, Emilio Custodio(3) ${ }^{(2 .}$. Vanderlinden ${ }^{(4)}$, J. Horacio Higueras ${ }^{(2)}$ y V. Giráldez ${ }^{(5)}$
\end{abstract}

(1) Instituto Geológico y Minero de España, Ríos Rosas 23, 28003 Madrid

(2) Universidad Politécnica de Cartagena. marisol.manzano@upct.es

(3) Universidad Politécnica de Cataluña y Real Academia de Ciencias de España.

(4) Instituto de Investigación y Formación Agraria y Pesquera (IFAPA).

(5) Universidad de Córdoba.

(6) anarebo@ @otmail.com

\begin{abstract}
This chapter presents the monitoring and research of groundwater resources and natural recharge in the Doñana Natural Area. The subchapter "Monitoring networks for Groundwater Resources and Recent Management Issues of the Doñana" deals with the history and current state of the official monitoring networks for piezometry and hydrochemistry. In the second subchapter "Application of Models in Recent Management and Forecasting of Resources" the current research and the model based water management issues are presented. The third subchapter "Main Knowledge existing on Groundwater Natural Chemical Composition and Contaminant Processes in the Eolian Mantle Aquifer Sector of the Doñana (SW Spain)" provides an overview of hydrochemical research carried out in the eolian part of the aquifer. Subchapter 4 "Active Monitoring Network for Recharge Measurements in the Doñana National Park" presents the current monitoring network for groundwater recharge.
\end{abstract}

Keywords: Doñana, groundwater resources, hydrochemistry, recharge.

\section{Redes de control y aspectos recientes de la gestión de los recursos hídricos y de la recarga en el acuífero Almonte Marismas (Doñana)}

\begin{abstract}
RESUMEN
Este artículo presenta la monitorización e investigación de recursos de aguas subterráneas y de recarga natural en el Espacio Natural de Doñana. El subcapítulo "Redes de control de los Recursos Hídricos Subterráneos de Doñana y aspectos recientes de su gestión" aborda la historia y el estado actual de la red oficial de control de piezometría e hidroquímica. En el segundo subcapítulo "Aplicación de modelos en la gestión reciente y pronósticos de recursos" se presenta la investigación actual y trabajos de gestión mediante modelación numérica. El tercer subcapítulo "Conocimiento de la composición hidroquímica y procesos de contaminación en el acuífero del manto eólico de Doñana (Suroeste de España)" proporciona un resumen de las investigaciones hidroquímicas realizadas en la parte eólica del acuífero. El subcapítulo 4 "Red de observación activa para medición de recarga en el Parque Nacional de Doñana" presenta la actual red de observación para la recarga de aguas subterráneas.
\end{abstract}

Palabras clave: Doñana, recursos hídricos subterráneos, hidroquímica, recarga. 
Claus Kohfahl, et al., 2019. Monitoring and current research of groundwater resources and... Boletín Geológico y Minero, 130 (4): $661-690$

\author{
VERSIÓN ABREVIADA EN CASTELLANO
}

\title{
Introducción
}

Este capítulo presenta la observación e investigación de los recursos de aguas subterráneas y de la recarga natural en el Espacio Natural de Doñana. El subcapítulo "Redes de control y aspectos de la gestión de los recursos hídricos en el acuífero Almonte Marismas (Doñana)" aborda la historia y el estado actual de la red oficial de control de piezometría e hidroquímica. En el segundo subcapítulo "Aplicación de modelos en la gestión reciente y pronósticos de recursos" se presenta la investigación actual y los trabajos de gestión mediante modelación numérica. El tercer subcapítulo "Conocimiento de la composición hidroquímica y procesos de contaminación en el acuífero del manto eólico de Doñana (Suroeste de España)" proporciona un resumen de las investigaciones hidroquímicas realizadas en la parte eólica del acuífero. El subcapítulo 4 "Red de observación activa para medición de recarga en el Parque Nacional de Doñana" presenta la actual red de observación para la recarga de aguas subterráneas.

Desde 1968 hasta la actualidad se ha creado una infraestructura generada por los diferentes organismos, que queda reflejada en la figura 2. La evolución de las redes está recopilada en la tabla 1 y en la figura 3 para el control cuantitativo y en la tabla 2 y en las figuras 4 para el control cualitativo. Las diferentes fases de la Planificación Hidrológica en este territorio han ido segregando el Sistema Acuífero Almonte-Marismas en sectores para desarrollar una gestión hidrogeológica optimizada e individualizada, primero como Unidades Hidrogeológicas y después como Masas de Agua Subterránea, que se pueden identificar con tres momentos en los sucesivos procesos de la Planificación Hidrológica (Figura 5). En este momento, el organismo competente de gestión constata que de las 8 Masas de Agua Subterránea que conforman el Sistema Acuífero Almonte Marismas, cuatro de ellas (Aljarafe Norte, Almonte, Marismas y La Rocina) no alcanzan el buen estado cuantitativo y otras cuatro (Aljarafe Norte, Almonte, Marismas y Condado) no alcanzan el buen estado químico por elevado contenido en nitratos (Segundo Ciclo de Planificación 2016-2021, BOE-A-2016-439).

\section{Aplicación de modelos en la gestión reciente y pronósticos de recursos}

El origen del uso de los modelos en Almonte-Marismas surge cuando la Organización de las Naciones Unidas para la Alimentación y la Agricultura (Food and Agriculture Organization, FAO) en la década de 1970 (Mortier et al., 1970), a través del Plan de Transformación, decide introducir grandes superficies de regadío. A través de ese primer modelo (IGME, 1976; Lucena y García, 1978) se buscaba la situación óptima de los sondeos de explotación y estudiar la afección de esas extracciones. Desde entonces, éste modelo ha sido actualizado continuamente dentro del IGME (IGME, 1982, Virgós et al., 1983; Virgós y Martín Machuca, 1995, UPC, 1999, Ledesma et al., 1999, Guardiola et al., 2004, 2005). El modelo con el que se ha trabajado comprende todo el acuífero Almonte-Marismas, excluyendo el acuífero del Aljarafe, y está desarrollado en el código MODFLOW, que describe el flujo tridimensional del agua subterránea y fue desarrollado por el Servicio Geológico de Estados Unidos (McDonald y Harbaugh, 1988). El área modelada está discretizada en dos capas, 174 filas y 154 columnas, con un tamaño uniforme de celda de $500 \mathrm{~m}$ × $500 \mathrm{~m}$ (Guardiola-Albert et al., 2009). Las condiciones de contorno coinciden con los límites del acuífero (Figura 6). Con el fin de realizar un modelo robusto con capacidad predictiva, inicialmente se construyó un modelo estacionario y se calibró mediante un mapa de isopiezas del año 1975. Partiendo de este modelo, se transformó a un modelo transitorio que ha sido calibrado y verificado continuadamente mediante los niveles piezométricos y caudales de explotación de los años correspondientes. El uso del modelo incluyó tanto los temas de gestión de los recursos hídricos como simulaciones de predicción enfocadas al efecto del cambio climático. Como resultado, se muestran en la tabla 3 los balances hídricos simulados entre 1975-1997 y los cambios pronosticados para la década de 2080. La figura 7 ilustra el descenso simulado en un escenario de gestión de reactivación de pozos cerca del municipio de Almonte. Finalmente, la tabla 4 presenta la disponibilidad de los recursos hídricos según el Plan Hidrológico 2016-2021 comparado con los resultados obtenidos mediante el modelo matemático.

\section{Conocimiento de la composición hidroquímica y procesos de contaminación en el acuífero del manto eólico de Doñana}

Desde 1985, diversos estudios hidrogeológicos han sido realizados por diversos autores en diferentes sectores del acuífero de Doñana. Entre los años 1992 y 2000, el Servicio Geológico de Obras Públicas y la Confederación Hidrográfica del Guadalquivir (CHG) construyeron 65 piezómetros multinivel con 2-4 niveles en cada ubicación. La mayor parte de la investigación se centró en el área arenosa occidental, que se conoce como el Manto Eólico de Doñana (Figura 8). La mayoría de las muestras de aguas subterráneas provienen 
Claus Kohfahl, et al., 2019. Monitoring and current research of groundwater resources and... Boletín Geológico y Minero, 130 (4): $661-690$

de pozos de una sola rejilla corta, algunas de pozos perforados con varios filtros o pozos abiertos y algunas de los manantiales que se muestran en la figura 9. La variabilidad de la composición del agua de lluvia por diferentes aportes atmosféricos de solutos se presenta en la figura 10. La variación de la composición hidroquímica de las 2 unidades del Manto Eólico queda reflejada en los diagramas de Stiff en la Figura 11. La figura 12 muestra la evolución hidroquímica observada a lo largo de un corte hidrogeológico paralelo al flujo y un gráfico de cajas que muestra variaciones desde el tipo $\mathrm{HCO}_{3}-\mathrm{Ca}$ o $-\mathrm{HCO}_{3} \mathrm{Cl}-\mathrm{NaCa}$ en la zona de la recarga hasta el tipo Cl- Na en la zona confinada de las marismas. Los valores de los parámetros estadísticos tanto del pH como de los solutos muestran que la química del agua subterránea natural es muy similar en ambas subunidades. La principal diferencia se muestra en $\mathrm{NO}_{3}, \mathrm{SO}_{4}, \mathrm{Co}, \mathrm{Cu}$ y $\mathrm{Zn}$, con mayores contenidos en la Unidad Eólica Superior, indicando una posible influencia causada por la aplicación de fertilizantes. Los contenidos de $\mathrm{NO}_{3}$ y $\mathrm{SO}_{4}$ en las muestras de agua subterránea en varios años entre 1992 y 2010 indican concentraciones más elevadas en los primeros $30 \mathrm{~m}$ del perfil del sedimento, lo que puede ser debido a un cambio de las condiciones redox o a un frente de aguas contaminadas avanzando en profundidad o una notable intercalación de baja permeabilidad (Figura 13). La figura 14 presenta la identificación de diferentes fuentes de $\mathrm{SO}_{4}$ y procesos de reducción química en las aguas subterráneas del Manto Eólico, indicando aerosoles de agua de mar y fertilizantes como fuentes principales de $\mathrm{SO}_{4}$. En la figura 15 se ilustra el origen del $\mathrm{NO}_{3}$, indicando los fertilizantes de amoníaco como principal fuente en el agua subterránea y la atmosférica. Las muestras de los excedentes de agua de riego están isotópicamente enriquecidas por desnitrificación y muchas muestras de aguas subterráneas también lo parecen. La figura 16 muestra el contenido de $\mathrm{NO}_{3}$ en la parcela del Tejar entre 1995 y 2009, después de que finalizara el cultivo, indicando una tendencia decreciente con la profundidad y que el $\mathrm{NO}_{3}$ mantiene concentraciones elevadas en la zona somera del acuífero. Los valores isotópicos de $\mathrm{NO}_{3}$ disuelto en 2009 revelan un origen ligado al estiércol, descartando la existencia de un frente de reducción alrededor de $25 \mathrm{~m}$ de profundidad.

Para investigar el origen de las concentraciones elevadas de arsénico (As) que se detectaron en 2008 durante la exploración del suministro de agua para el Palacio de Marismillas (Figura 1), se realizó un estudio adicional en 2012 y 2013 (Kohfahl et al., 2016). A una escala mayor, se analizaron muestras de 13 piezómetros y 50 de agua superficial en todo el Parque Nacional. Las muestras de sedimento inalteradas se analizaron para determinar parámetros físicos, mineralogía y geoquímica. Los resultados del muestreo de agua subterránea indicaron una fuerte correlación de As con Fe ${ }^{2+}$, apuntando a la movilización de As debido a la disolución por reducción de los óxidos hidroférricos (HFO) en áreas de contenidos elevados de materia orgánica dentro de los sedimentos. Las altas concentraciones de As en las aguas superficiales se relacionaron con la alcalinidad y el $\mathrm{pH}$ elevado, dando lugar a la desorción de As en los HFO. El metabolismo de las algas es responsable de la presencia de especies de arsénico metilado en el agua superficial, en contraste con el agua subterránea, en la que solo se encontraron especies inorgánicas de As.

\section{Red de observación activa de mediciones de recarga en el Parque Nacional de Doñana}

La infraestructura total consiste en un meteo-lisímetro de pesada de alta precisión y mediciones adicionales de los parámetros meteorológicos y parámetros del suelo, así como el nivel del agua subterránea, la conductividad eléctrica y la temperatura en diferentes emplazamientos como se muestra en la figura 17 y la tabla 5. La evolución de los parámetros respectivos queda reflejada en la tabla 6. El ruido intrínseco en los datos del lisímetro se filtra mediante el programa AWAT (Peters et al., 2014). Los primeros resultados muestran los datos registrados del peso del lisímetro y del drenaje cumulativo sin tratamiento previo desde diciembre de 2015 hasta septiembre de 2016, que se representan en la figura 18. La figura 19 recoge la temperatura del aire y del suelo a diferentes alturas y profundidades. En la figura 20 se muestran las series cronológicas registradas de la humedad del suelo, la precipitación, la temperatura y la conductividad de los poros en 3 ubicaciones del emplazamiento de Marismillas, desde enero de 2013 hasta julio de 2017. Los componentes del balance de agua del suelo medidos por el lisímetro en el año hidrológico 2016/2017 se compilan en la tabla 7 . Los datos obtenidos se utilizan actualmente para (i) contrastar la recarga obtenida mediante el programa HYDRUS1D, (ii) para investigar el papel del rocío en el balance hídrico del suelo, (iii) para determinar el efecto del flujo térmico y del vapor y (iv) para contrastar diferentes métodos de medición de precipitación. Además, las estimaciones de recarga y su dependencia de los parámetros meteorológicos medidos se utilizarán para generar series temporales futuras de recarga basadas en los datos de temperatura y precipitación pronosticados por los modelos climáticos regionales (Regional Climate Models, RCMs). 


\section{Introduction}

The Doñana Natural Area is located in the province of Huelva (Andalusia), southern Spain, between the western bank of Guadalquivir River and the Atlantic Ocean, comprising two administrative areas which are the National Park $(54,252$ ha) and the Natural Park $(68,236$ ha) (Fig. 1).

Created in 1969, the National Park was subsequently expanded and integrated into the Ramsar Convention protected wetland area in 1982. The climate is sub-humid Mediterranean (Siljeström et al., 2002) with three dominant ecosystem types which are (i) phytostable, semistable, and moving dunes with more than 3,000 small temporary ponds (GómezRodríguez et al. 2011), (ii) current and relict beaches and (iii) marshes. The geographical position of Doñana has given rise to abundant and diverse flora and fauna and is especially critical to bird diversity. More than 600,000 water birds use the area for wintering or migration to and from Africa (Martí et al., 2002), constituting one of the most important sites for wintering waterfowl in the Western Palearctic (Scott et al., 1996).

The hydrodynamics of the park is controlled by the two main rivers, the Guadalquivir River and its affluent, the Guadiamar River. Surface water is limited to a couple of small groundwater-fed permanent rivers and some seasonal brooks, some permanent lagoons, several hundreds of temporal lagoons in small depressions where the water table crops out, and several hundreds of artificial ponds to water cat-

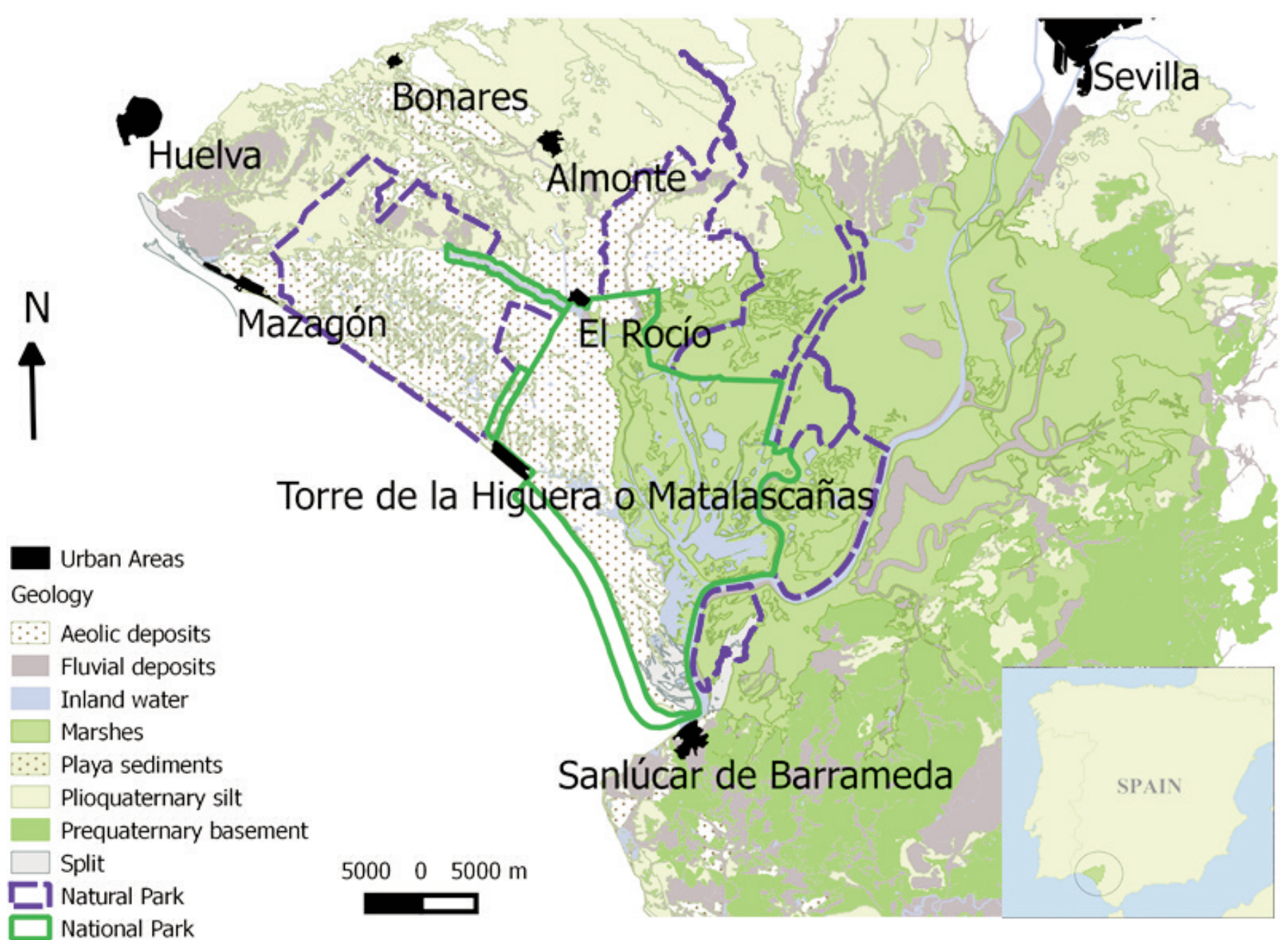

Figure 1. Protected wetland area and surroundings of the Doñana Natural Area. Geology simplified after MAGNA 50 (Mapa Geológico de España a escala 1:50.000 ( $2^{\mathrm{a}}$ Serie).

Figura 1. Zona protegida de la marisma y alrededores del Area Natural de Doñana. Geología simplificada de serie MAGNA 50 (Mapa Geológico de España a escala 1:50.000 (2 ${ }^{a}$ Serie)). 
tle, forming a system of temporary water bodies of remarkable singularity in Europe with a high protection status (Williams et al., 2001).

The uppermost sediments of the Doñana natural region are built up by unconsolidated Plio-Quaternary materials constituting fluvio-marine and alluvial sands, gravels and silts having a variable thickness from a few metres inland to some $150 \mathrm{~m}$ at the coastline, forming the regional Almonte-Marismas aquifer (Custodio et al., 2009). To the west, they are covered by aeolian sands of a dune belt, whereas in the eastern part they are overlain by fine grained estuary sediments of the salt marshes.

Doñana is surrounded by 46 villages and towns with a total population of about 1.5 million people. Additionally, the area is located at the mouth of the Guadalquivir River, whose basin is inhabited by more than 4 million people (Delgado et al., 2017). The greatest external challenges constitute agriculture and tourism, which extract significant amounts of groundwater which then alter the hydrological dynamics requiring active management of groundwater resources.

The following subchapters will give a brief overview about (i) the historical development of the groundwater monitoring network, (ii) the model based interpretation of the obtained monitoring data, (iii) the current knowledge about the natural hydro- chemical groundwater composition and contaminant processes, and (iv) the active monitoring network for recharge measurements.

\section{Monitoring of groundwater resources in Doñana and recent management issues}

\section{Creation of groundwater infrastructure}

The first study related to the groundwater of the Almonte-Marismas Aquifer System initiated with the Guadalquivir-FAO Project (FAO, 1970) was executed by the Food and Agriculture Organization (FAO) and the Geological Survey of Spain (Spanish acronym IGME). This project was carried out between 1965 and 1975 in three consecutive phases (FAO, 1970; FAO, 1972, and FAO, 1975). The outcome of this project, in terms of infrastructure in the Almonte-Marismas area, was the inventory of 1,416 points of water and 68 exploratory boreholes equipped as piezometers (Fig. 2A).

A consequence of this project was an exploratory borehole drilling campaign by the National Institute of Agrarian Reform and Development (IRYDA) directed by the Spanish Geological and Mining Institute where a total of 460 boreholes were drilled (IRYDA, 1976). In 1991, within the framework of the new Water
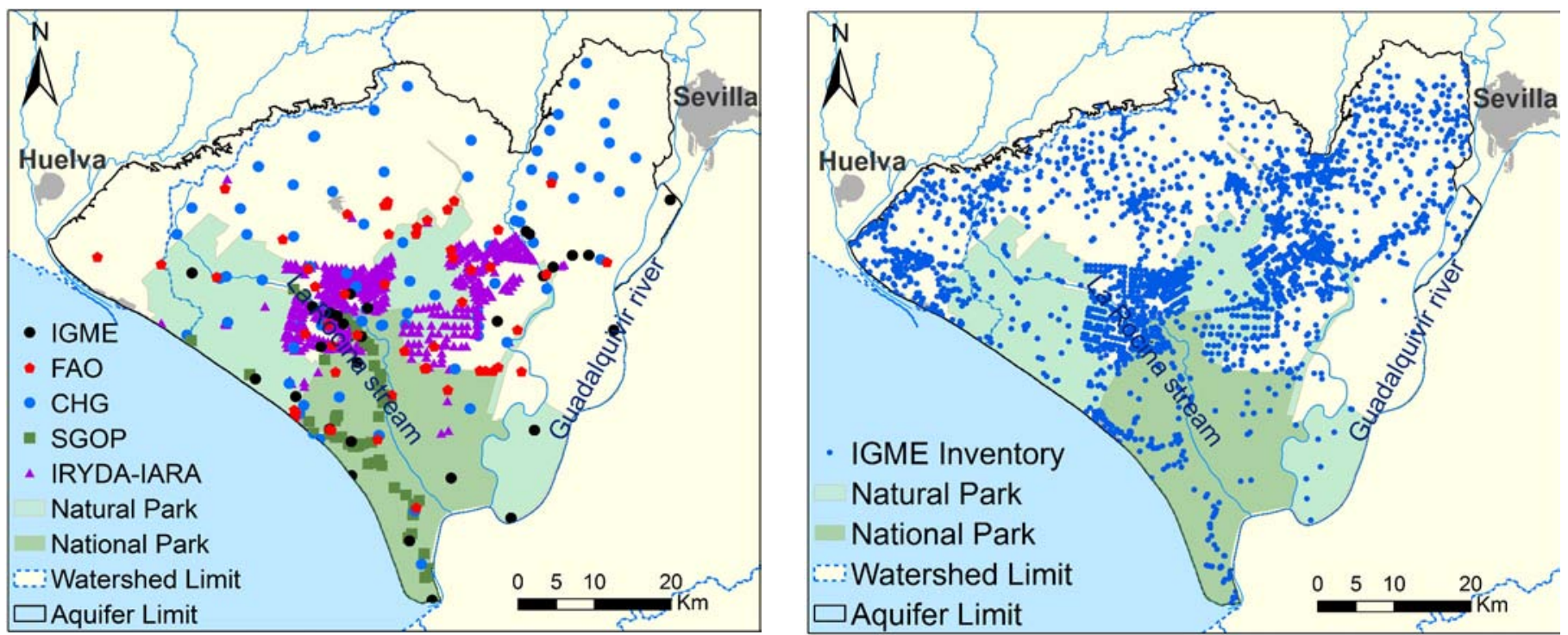

Figure 2. Groundwater infraestructures A: (left). Hydrogeological monitoring infrastructure of the different organisms in 2017. B: (right). Inventory of wells of the IGME in 2017. IGME, SGOP, IRYDA-IARA and CHG are Spanish Acronyms for Spanish Geological Survey, Geological Survey of Public Works. National Institute of Agrarian Reform and Development and Guadalquivir Basin Water Authority, respectively.

Figura 2. Infrastructuras de agua subterránea A: (izquierda). Infraestructura hidrogeológica de observación de los diferentes organismos en 2017. B: (derecha). Inventario de pozos del IGME en 2017. IGME, SGOP, IRYDA-IARA y CHG son los acrónimos de Instituto Geológico y Minero de España, Servicio Geológico de Obras Públicas, Instituto Nacional de Reforma y Desarrollo Agrario y Confederación Hidrográfica del Guadalquivir, respectivamente. 
Claus Kohfahl, et al., 2019. Monitoring and current research of groundwater resources and... Boletín Geológico y Minero, 130 (4): $661-690$

Law (BOE-A-1985-16661), the Guadalquivir Basin Water Authority initiated the construction of a number of multiple piezometers in specific areas of great ecological interest, advised by the Technical University of Catalonia and the Spanish Geological Survey. Thus, a total of 100 piezometers were built on 58 sites between 1991 and 1995. In late 1992, the Guadalquivir Basin Water Authority, launched the project Design and execution of boreholes for a piezometric monitoring network in Hydrogeological Unit 05.51 (Almonte-Marismas) (CGS, 1994-1996). 55 piezometers located on 22 sites were installed within the framework of this project. The most recent actions by the Guadalquivir Basin Water Authority with regard to the creation of infrastructure for monitoring groundwater are the implementations of 114 piezometers distributed throughout the entire basin 13 of which are located within the Almonte-Marismas aquifer system - between 2007 and 2009. As a result of the different specific agreements signed between the Spanish Geological Survey and the Ministry of Environment, a total of 33 mechanically drilled boreholes for geological exploration located on 22 sites and equipped with piezometers were built between 1999 and 2007. In addition to all these major hydrogeological projects, there are others that are much more specific carried out by different universities and the IGME itself, which also have led to the creation of the hydrogeological infrastructure (among others ITGE, 1991; Serrano and Serrano, 1996; Olías et al. 1996; Rodríguez, 1998; Iglesias, 1999; Muñoz-Reinoso, 2001; Lozano, 2004; Higueras, 2014).

As a consequence of all these projects carried out by the various authorities, a dense network of hydrogeological infrastructure that extends unevenly throughout the Almonte-Marismas aquifer system has been created, as can be seen in Figure 2A. The inventory has been updated, and currently the Water
Points Database of the Spanish Geological Survey includes 2,520 points (Fig. 2B).

\section{Piezometric monitoring networks}

The first organism that officially initiated the measuring of the piezometric levels on a regular basis was the Spanish Geological Survey, from 1968 to 2001, when the Guadalquivir Basin Water Authority took over the monitoring network. Simultaneously, other organisms have maintained smaller networks without maintaining regular measurements, such as the National Institute of Agrarian Reform and Development and the National Institute for the Conservation of Nature (Spanish acronym ICONA). Since 2017, the monitoring of the quantitative status (Basic Piezometric Monitoring Network) depends on the respective legal authorities called the River Basin Districts (RBD). Apart from this, the Guadalquivir Basin Water Authority manages a Supplementary Piezometric Monitoring Network and the Spanish Geological Survey continues to measure a number of points within the project Improvement of the mathematical model of the Almonte-Marismas aquifer as support to the management of water resources: estimation of the recharge, stochastic model, and update (amongst others: Guardiola-Albert et al., 2016; IGME, 2009). The evolution of the quantitative monitoring networks is compiled in Table 1 and Figures $3 \mathrm{~A}$ and $\mathrm{B}$.

\section{Hydrogeological instrumentation of the piezometric monitoring networks}

All these piezometric networks were monitored primarily using manual portable water level meters with a maximum measurement frequency on a monthly

\begin{tabular}{|l|l|l|l|}
\hline Organism & \multicolumn{1}{|c|}{ Period } & Number of Points & \multicolumn{1}{|c|}{ Sampling interval } \\
\hline Spanish Geological Survey (IGME) & $1968-2001$ & $45-300$ & monthly/biannual \\
\hline National Institute of Agrarian Reform and Development (IRYDA-IARA) & $1975-2003$ & 100 & fortnightly/quarterly \\
\hline National Institute for the Conservation of Nature (ICONA) & $1987-1990$ & 34 & monthly \\
\hline Guadalquivir Basin Water Authority (CHG): additional network) & $1991-2017$ & $180-273$ & monthly \\
\hline Spanish Geological Survey (IGME) & $2006-2017$ & 170 & monthly \\
\hline River Basin District (RBD) Guadalquivir & $2009-2017$ & $80-90$ & monthly \\
\hline River Basin District (RBD) Tinto-Odiel-Piedras & $2009-2017$ & 7 & monthly \\
\hline
\end{tabular}

Table 1. Historical evolution of the piezometric networks. (Unpublished database of IGME, Guadalquivir Basin Water Authority CHG and the Tinto-Odiel-Piedras Basin Water Authority TOP). RBD=River Basin District.

Tabla 1. Evolución histórica de la red piezométrica. (Base de datos no publicada del IGME, Confederación Hidrográfica del Guadalquivir CHG y Confederación Hidrográfica delTinto-Odiel-Piedras). RBD=Área de la Cuenca Hidrográfica. 

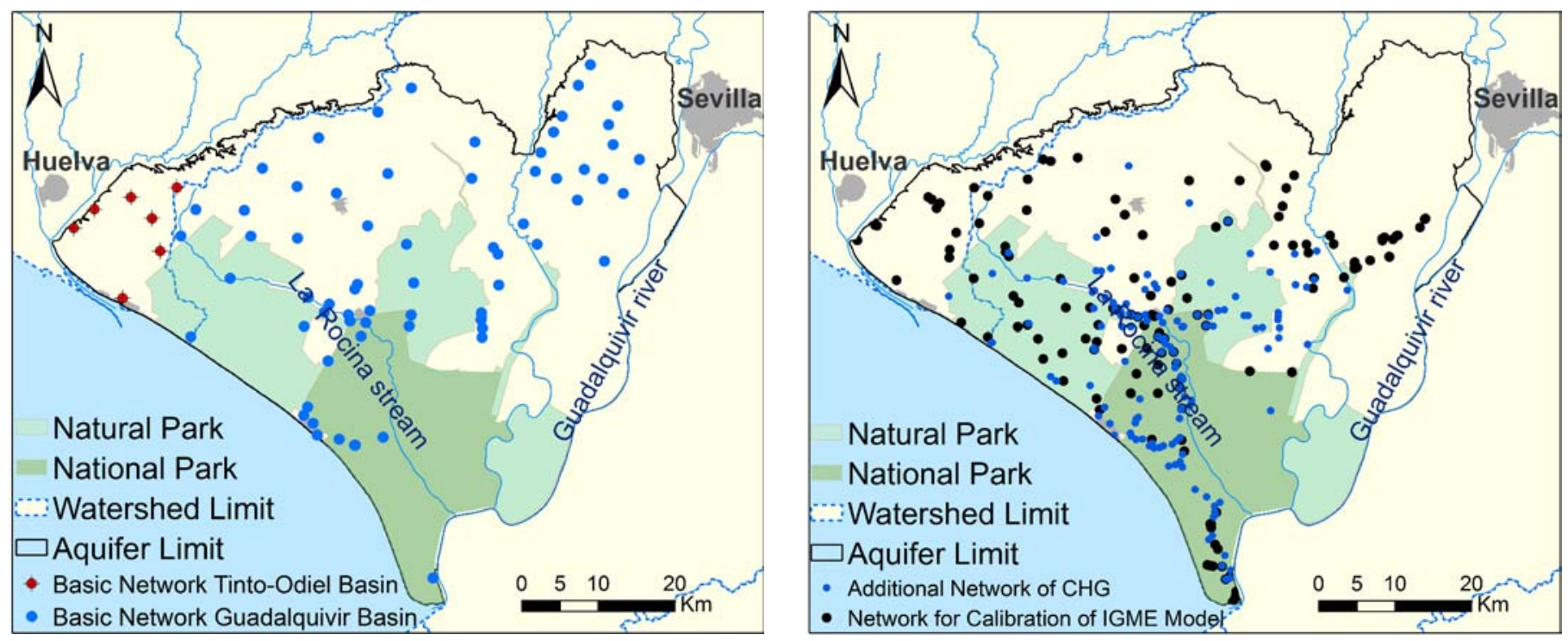

Figure 3. A: (left). Distribution of basic piezometric monitoring networks of the respective Water Authorities for the Guadalquivir Basin and Tinto Odiel Piedras Basin. B: (right). Additional piezometric monitoring networks of the Guadalquivir Basin Water Authority (CHG) and the Spanish Geological Survey (IGME) (Unpublished database CHG and IGME).

Figura 3. A: (izquierda). Distribución de la red de monitoreo básico de las respectivas autoridades de las cuencas hidrográficas del Guadalquivir y Tinto Odiel Piedras. B: (derecha). Red adicional de monitoreo de la Confederación Hidrográfica del Guadalquivir (CHG) y del Instituto Geológico y Minero de España (IGME) (Base de datos no publicada de CHG e IGME).

basis. In 1996, the Guadalquivir Basin Water Authority provided a total of 39 continuous water level data loggers on 27 sites; some of them were operating until 2008 (Palancar, 2000). Since 2001, the IGME has also installed additional water level data loggers and currently (in 2017) operates 56 sensors on 45 sites with logging intervals according to the objectives of the relevant framework project (amongst others: AntónPacheco et al. 2009; Rebollo et al. 2008).

\section{Quality monitoring networks}

With regard to the networks for monitoring quality, in 1982 the Spanish Geological Survey (IGME) installed a quality network and a network to monitor saltwater intrusion, as summarised in Table 2 and Figure 4A. Since 2005, the Guadalquivir and Tinto-Odiel-Piedras (TOP) River Basin Districts (RBD) have jurisdiction over the quality networks (Table 2 and Figure 4B).

\section{Recent aspects of managing the groundwater resources}

To facilitate optimised and more individualised groundwater management, the Guadalquivir Basin Water Authority divided the Almonte-Marismas aquifer system into different sectors, by defining the Hydrogeological Units (Spanish acronym UUHH) in a

\begin{tabular}{|c|c|c|c|}
\hline Organism/Type of Network & Period & Number of Points & Sampling frequency \\
\hline Spanish Geological Survey (IGME)/ Saline Intrusion & $1982-2003$ & $5-10$ & quarterly \\
\hline River Basin District (RBD) Guadalquivir /Quality and piezometry & $2005-2017$ & $10-15$ & biannual \\
\hline River Basin District (RBD) Tinto-Odiel-Piedras /Quality and piezometry & $2009-2017$ & 10 & biannual \\
\hline
\end{tabular}

Table 2. Historical evolution of groundwater quality networks (Unpublished database Guadalquivir Basin Water Authority, Tinto-OdielPiedras River Basin District and Spanish Geological Survey).

Tabla 2. Evolución histórica de la red piezométrica (Base de datos no publicada de la Confederación Hidrográfica del Guadalquivir CHG, Confederación Hidrográfica del Tinto-Odiel-Piedras e IGME). 

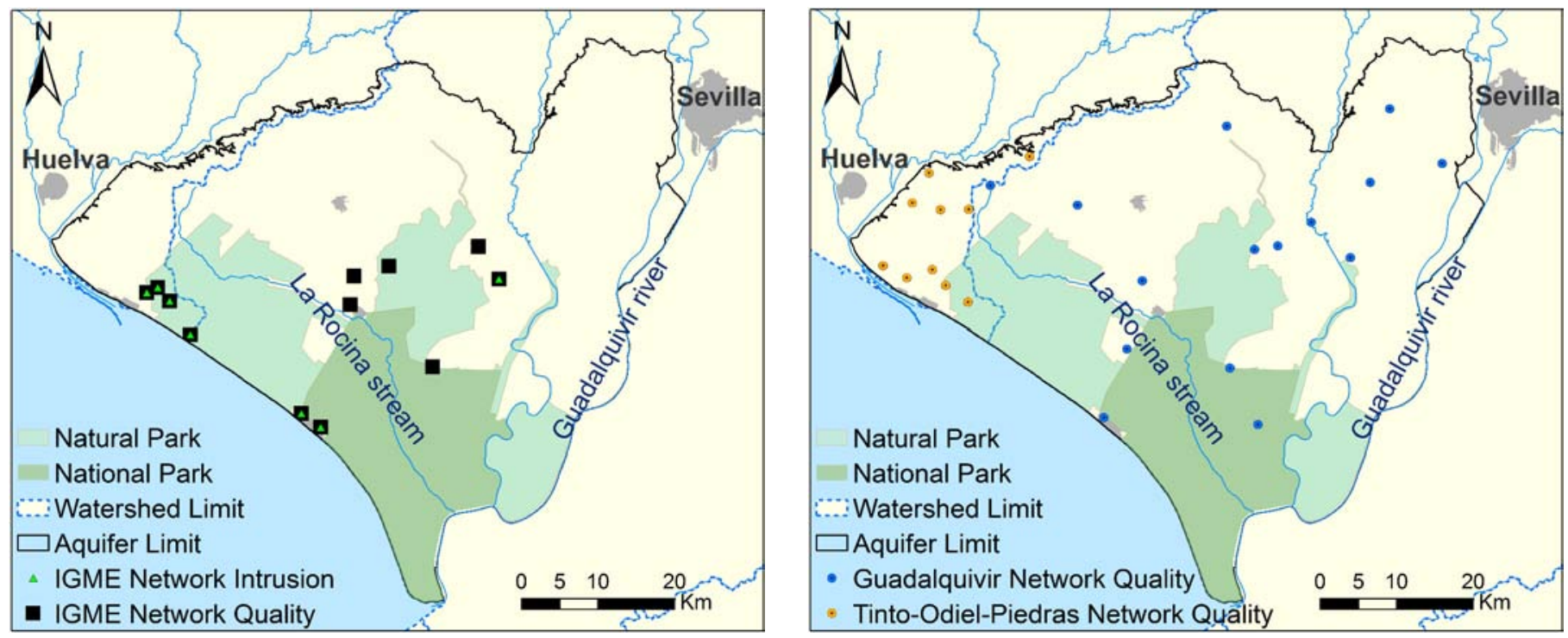

Figure 4. A: (left). IGME groundwater quality network for historical quality and saline intrusion (Unpublished IGME database). B: (right). Groundwater quality network of the Guadalquivir and Tinto-Odiel-Piedras Basin Authorities (Unpublished databases River Basin District Guadalquivir andTinto-Odiel-Piedras).

Figura 4. A: (izquierda). Red histórica de calidad para monitoreo de calidad e intrusión salina del IGME (Base de datos no publicada del IGME). 4B: (derecha). Red de calidad de las aguas subterráneas de las autoridades de Cuenca del Guadalquivir y Tinto Odiel Piedras (Bases de datos no publicadas por las autoridades de cuenca del Guadalquivir y Tinto-Odiel-Piedras).

first step and the groundwater bodies (Spanish abbreviation MASb for Masas de Agua Subterránea), in a second and third step (Fig. 5).

The division of the Almonte-Marismas Aquifer System requires the use of a numerical model to estimate the groundwater transfer between the defined groundwater bodies. The model has been updated and improved by the Spanish Geological Survey for the past several years, as specified in the subchapter below (Amongst others: Guardiola-Albert et al. 2016; IGME, 2009).

\section{Brief summary of the current state of water resources and their evolution}

The historical and present use of natural groundwater resources of the Doñana is significant and has severe

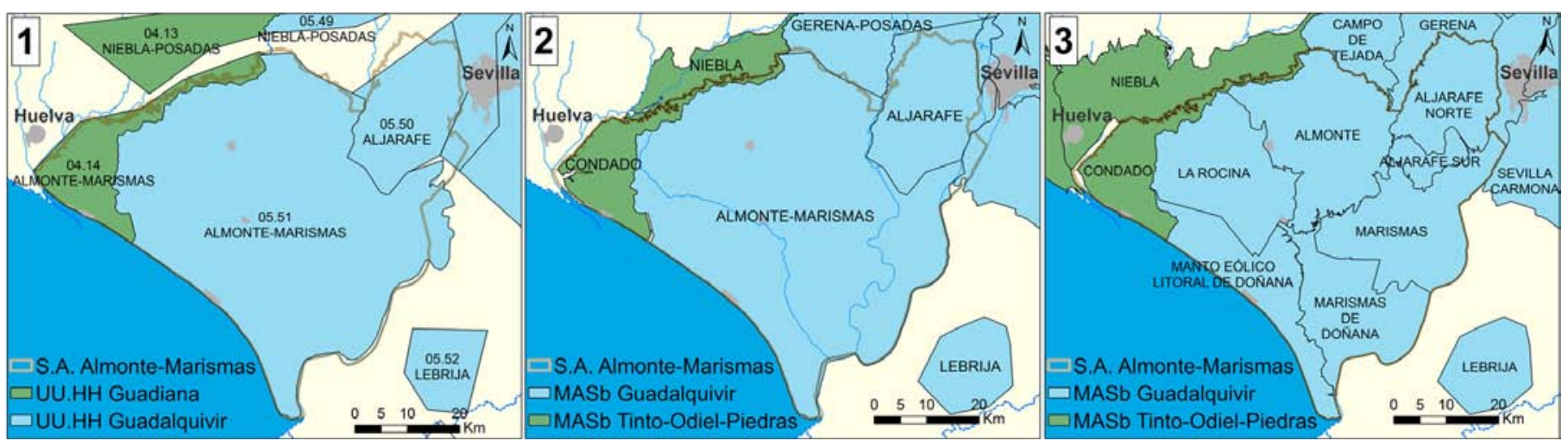

Figure 5. Almonte-Marismas Aquifer System (Spanish S.A. Almonte Marismas) divided into: 1) Hydrogeological Units (UU.HH), (BOE-A2001-13042). 2) Groundwater bodies (MASb) first management period 2009-2015, (BOE-A-2013-5319). 3) Groundwater bodies (MASb) second management period 2016-2021, (BOE-A-2016-439).

Figura 5. Sistema Acuífero Almonte-Marismas (S.A. Almonte Marismas) dividido en: 1) Unidades Hidrogeológicas (UU.HH), (BOE-A-200113042). 2) Masas de agua subterránea (MASb) primer plan de gestión 2009-2015, (BOE-A-2013-5319). 3) Masas de agua subterránea (MASb) Segundo plan de gestión 2016-2021, (BOE-A-2016-439). 
long-term effects because there is a direct relation between the groundwater head, the discharge and the conservation of the wetlands. The agricultural extractions for irrigation have caused a general decline in groundwater piezometric levels, which is very pronounced in certain areas (Custodio et al. 2008). The result is a gradual decline of discharge into creeks and marshes as well as a water-table decline in the areas of groundwater dependent vegetation (Manzano et al. 2005). In 2017, the management authority confirmed that, of the eight groundwater bodies making up the Almonte Marismas Aquifer System, four of them (Aljarafe Norte, Almonte, Marismas and La Rocina) did not reach good quantitative conditions and another four (Aljarafe Norte, Almonte, Marismas and Condado) did not reach good chemical conditions due to the high nitrate content (Second Planning Cycle 2016-2021, BOE-A-2016-439).

\section{Application of models in recent management and forecasting of resources}

Mathematical modelling of groundwater flow can be used to simulate different management strategies, allowing the selection of the best option to fit the water requirements of the system and therefore provide an efficient water management tool. In particular, the mathematical model operated by the Spanish Geological Survey (IGME) for the Almonte-Marismas aquifer significantly improves the choice of optimal management strategies of the Doñana groundwater resources and its groundwater dependent ecosystem.

The use of the groundwater models for the Almonte-Marismas aquifer dates back to the 1970s, when the Food and Agriculture Organisation decided to include large areas of the Doñana salt marshes for irrigation (Mortier et al., 1970). The first model (IGME, 1976; Lucena and Garcia, 1978) sought the optimal location of the exploratory boreholes and the effects due to their groundwater extractions. From this time, this model has been updated continuously by the Spanish Geological Survey, integrating hard- and software development and the increasing hydrogeological information (IGME, 1982, Virgós et al., 1983; Virgós \& Martín Machuca, 1995, UPC, 1999, Ledesma et al., 1999, Guardiola et al., 2004, 2005).

In this subchapter we present the current model version operated by the Spanish Geological Survey in 2017, highlighting in particular its contributions to improve the management of the groundwater resources of the Doñana. Different model applications are also included, such as an impact analysis of different climate scenarios, a model based evaluation of a specific management scenario to improve the urban water supply and a model based estimation of the available resources of the EI Rocío groundwater body.

\section{Methodology}

The model includes the entire Almonte-Marismas aquifer, except for the Alajarafe aquifer, and is developed based on MODFLOW, a three-dimensional finite difference code developed by the United States Geological Survey (McDonald and Harbaugh, 1988). Specifically, Visual MODFLOW 4.3 currently marketed by Schlumberger was used.

The modelled area is discretised in two layers, 174 rows and 154 columns, with a uniform cell size of 500 $\mathrm{m} \times 500 \mathrm{~m}$ (Guardiola-Albert et al., 2009). The hydraulic conductivity values range from 0.001 to 50 $\mathrm{m} / \mathrm{d}$. The boundary conditions were established along the edges of the aquifer (Fig. 6).

To obtain a robust model with prognostic capacity, initially a steady state model was set up and calibrated for the measured groundwater contours of 1975 . Afterwards, the steady state model was upgraded to a transient model that has been continuously calibrated and verified by the observed hydraulic heads and groundwater extractions.

\section{Results}

\section{Simulation of different climate scenarios}

According to the results provided by officially accepted climate models, it is expected the available water resources will undergo variations due to climate change, producing an increase in evaporation, more intense periods of rainfall and more extreme hydrological events such as floods and droughts (IPCC 2007). Global climate models (GCM) predict an increase in the average temperature in the area of Doñana of between $1.2{ }^{\circ} \mathrm{C}$ and $7.4{ }^{\circ} \mathrm{C}$ for the period 2071-2100. Less significant changes are expected with regard to precipitation.

Time series of future precipitation and potential evaporation (calculated from the temperature) predicted by 13 global climate models were implemented in the groundwater model to simulate the impact of climate change on the water resources (GuardiolaAlbert and Jackson, 2011). The piezometric and water balance changes in the 13 simulations were analysed in comparison with the historical series. The historical groundwater discharge (1975-1997) compared with the simulated values for future scenarios in $\mathrm{hm}^{3} /$ year 

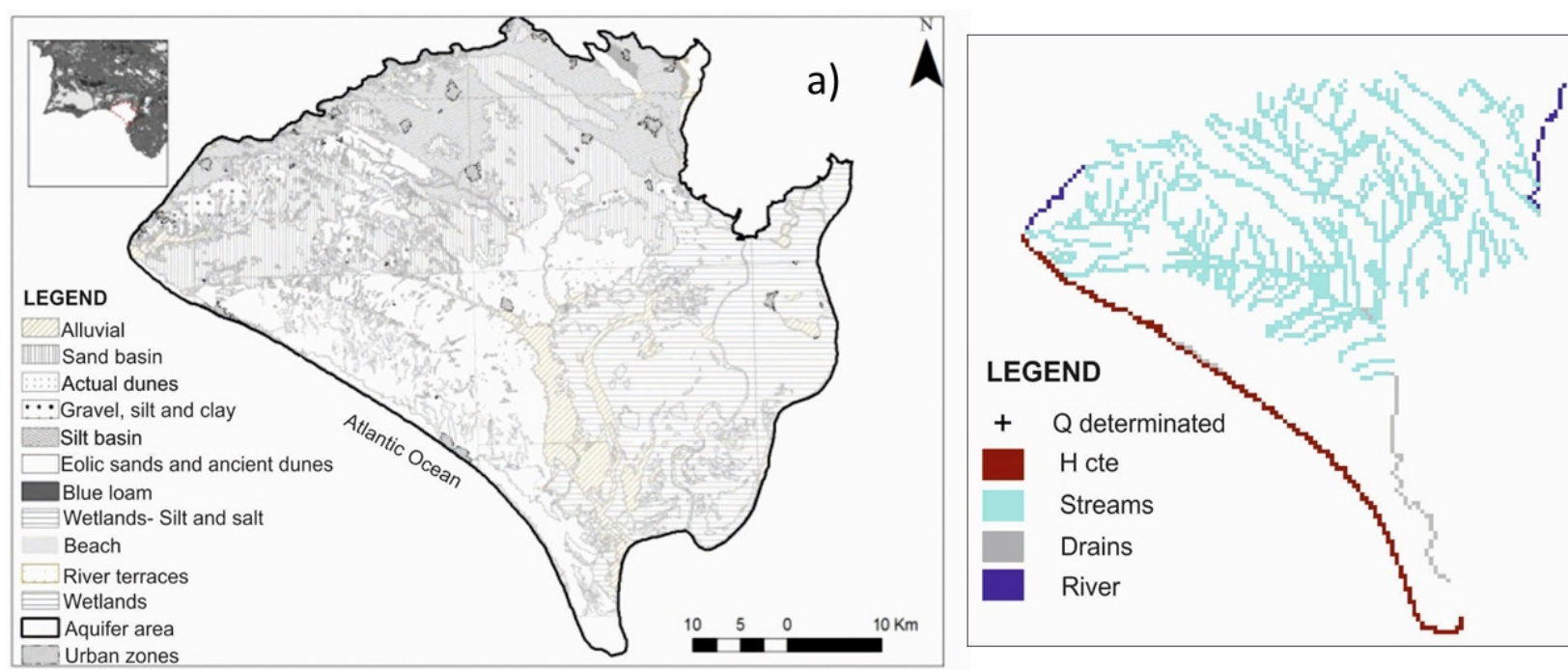

b)

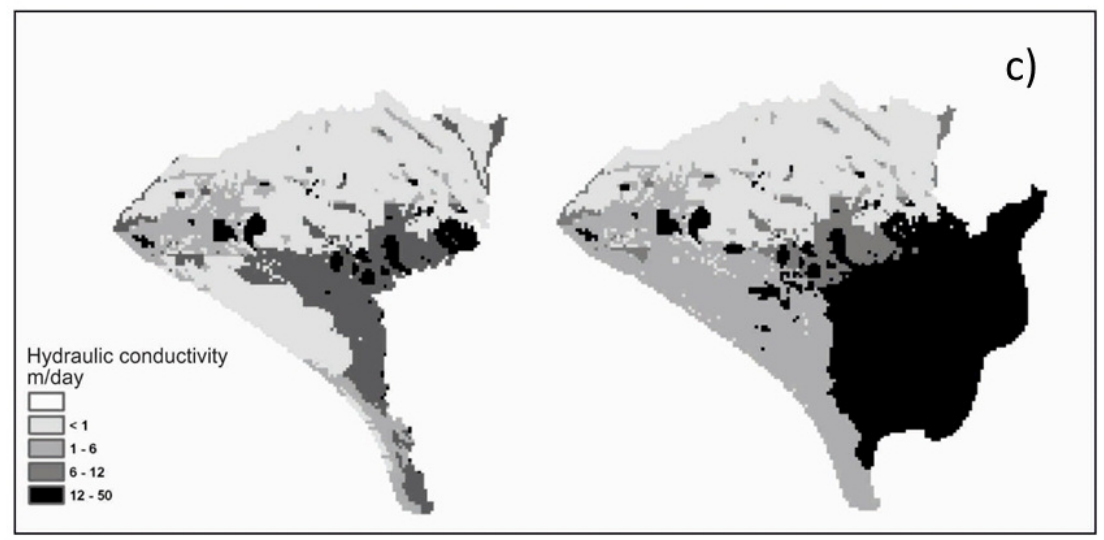

Figure 6. a) Geology. b) Model boundary conditions with $\mathrm{Q}=$ user defined flow, $\mathrm{H}$ cte =constant hydraulic head of Atlantic Ocean. Stream, drain and river represent $3^{\text {rd }}$ type Cauchy boundary conditions with specified constant head. c.) Horizontal hydraulic conductivity distribution of the two model layers where the white zones within the model area represent inactive cells. The left layer represents the upper layer and the right one the lower layer.

Figura 6. a) Geología. b) Condiciones de contorno del modelo con $Q$ = flujo definido por el usuario, $H$ cte = definida por el Océano Atlánico. Arroyos, drenes y rio representan al tercer tipo de la condición de Cauchy con nivel constante c.) Distribución de la conductividad hidráulica horizontal de las dos capas del modelo donde las zonas blancas representan celdas inactivas. La capa de la izquierda representa la capa de arriba y la de la derecha la de abajo.

suggest a significant discharge decrease during this century, exceeding the current extractions via pumping by a factor of between 1.5 and 2.4 (Table 3). Since these simulations are based on potential evaporation, the decrease of hydraulic head and discharge has to be interpreted as maximum values, especially for the dune belt area, where the groundwater levels are several metres below surface.

To sum up, climate change projections predict a reduction in recharge of between $14 \%$ and $57 \%$ and, therefore, in the flow from the aquifer to creeks, drains and marshes. This decrease in groundwater flow towards surface waters is, in general, greater than that of direct extractions from the aquifer. Looking at these results, they demonstrate once again that groundwater resources management strategies are necessary in order to respond to the impact of future climate change.

\section{Simulation of management scenarios}

The model has also been used to study the impact of the following management scenarios at different sites:

- Rising groundwater levels after termination of 


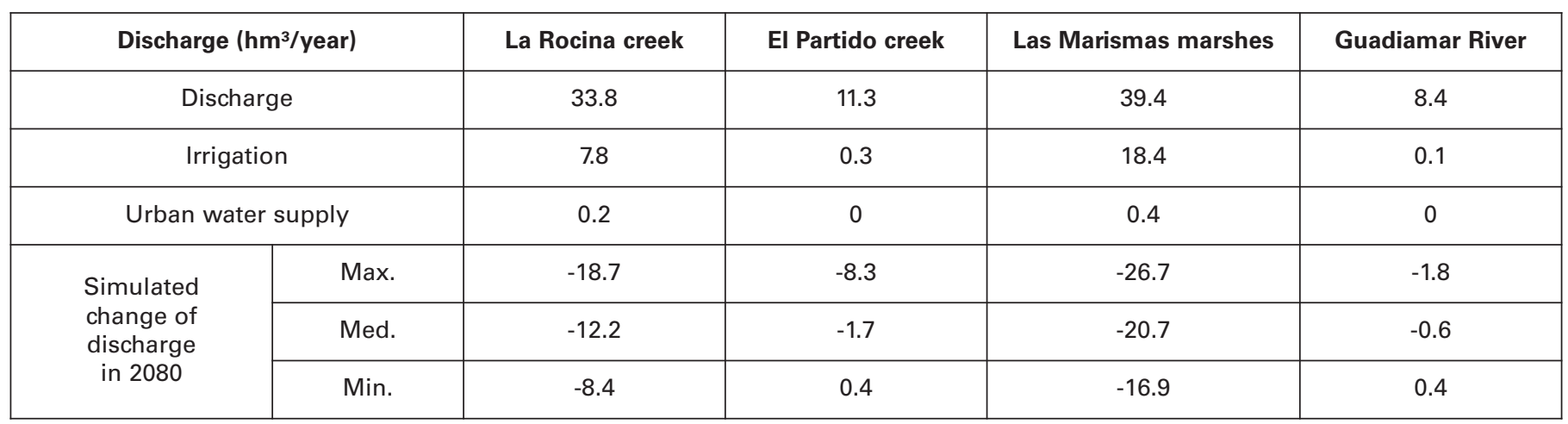

Table 3. Simulated groundwater discharge between 1975-1997 and simulated changes for the decade of the 2080 s.

Tabla 3. Descarga de aguas subterráneas simulada entre 1975-1997 y cambios simulados para la década de 2080.

groundwater extractions north of the Rocina Creek.

- Groundwater drawdown due to $20 \%$ increased groundwater extraction for the water supply of Matalascañas.

- Hydraulic head evolution after termination of groundwater extractions in the Los Hatos area.

- Feasibility study of the reactivation of 10 wells owned by the National Institute of Agrarian Reform and Development (IRYDA) in the municipality of Almonte to improve the urban water supply.

- Resettlement of farming fields at the upper reaches of the Rocina creek to environmentally less sen- sitive areas, away from creeks and ecological corridors.

All these scenarios analyse the evolution of the hydraulic head, the exchange of flows, the influence on the various terms of water balance, etc. The first three problems have been described in GuardiolaAlbert et al. (2005; 2007 and 2008). They all show the impact of the actions studied on areas of high ecohydrological interest (lagoons, creeks, marshes, etc.) in terms of the hydraulic head and the contributions of groundwater to these areas.

By way of example, we show what would happen if the IRYDA wells started to operate in the municipality of Almonte, based on the hydraulic head at the end
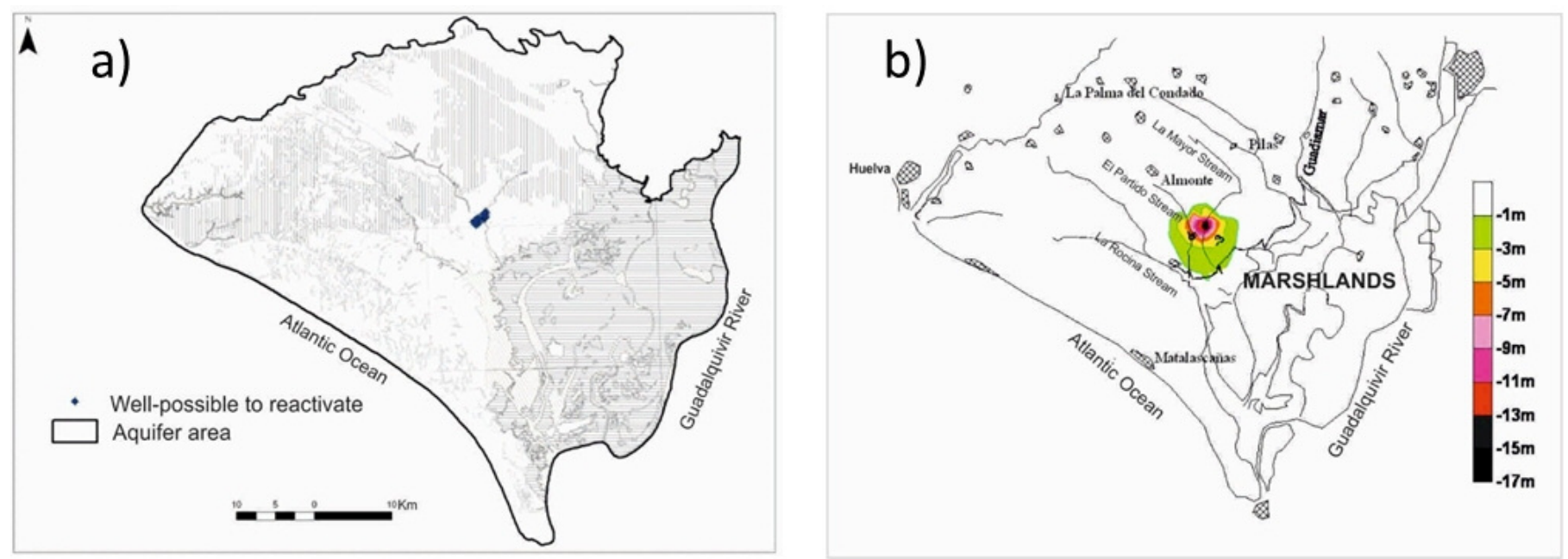

Figure 7. a) Groundwater extraction sites. b) Simulated decrease of groundwater level after 10 years of reactivation of groundwater extraction.

Figura 7. a) Lugares de extracción de agua subterránea. b) Descenso simulado del nivel piezométrico tras 10 años de reactivación de la extracción de aguas subterráneas. 
of 2004. To illustrate the effect of the reactivation of the wells, we calculated the difference between the hydraulic head obtained and the two simulations after 10 years have elapsed (Fig.7). The differences range between 5 and $17 \mathrm{~m}$ around the El Partido and La Mayor creeks, with an effect extending to the limit of the marshes. On the other hand, it was concluded that, in the short period considered, there would not be any direct effects on groundwater discharge to the marsh.

\section{Estimate of available groundwater resources}

To improve groundwater management issues, in the 2016-2021 Hydrological Plan for the Guadalquivir River Basin District (Spanish acronym PHG), the Almonte-Marismas aquifer system (formerly MASb 05.51) was divided into five different groundwater bodies (MASb), not including the Aljarafe aquifer. This makes the calculation of these resources in the 5 MASb considered in the area of Doñana a difficult task with complex interpretation. The available natural groundwater resources, according to the Hydrological Planning Instruction, cover all inputs to the MASb, except drains to rivers, creeks, springs, and the sea. According to this definition, and using the model, the estimates of water resources available in the Doñana area are summarised in Table 4.

The estimates of available natural groundwater resources defined by the PHG for the 2008-2014 period differ from those calculated by the model, obtaining much higher values with the model except for the Almonte MASb. These differences are related to the different methods used for recharge estimation but also to higher precipitations during 2008-2014 com- pared with the historical period, leading to a $30 \%$ increase of model estimated infiltration recharge.

\section{Main knowledge existing on natural chemical composition of groundwater and contaminant processes in the eolian mantle aquifer sector of the Doñana (SW Spain)}

Throughout the centuries, the Doñana aquifer has played a main role in sustaining both the environment (feeding freshwater creeks, lagoons and ponds, maintaining the phreatophyte forest and generating nesting and growing conditions for wild fauna throughout the year) and, more recently, the economy of the local population (through irrigated agriculture since the middle of the 1970 s and environmental tourism). However, the intensive groundwater exploitation since the early 1980s, mostly for irrigation and to supply touristic areas, raised concerns about the effects of groundwater level drawdown and about pollution by agrochemicals.

Since 1985, many hydrogeological studies have been carried out by diverse authors in different sectors of the Doñana aquifer. Some chemical information generated before 1995 contained a notable uncertainty about the impact of groundwater exploitation or the possible existence of agricultural pollution, because most of the available sampling points (exploitation wells with long screened sections) were not adequate to provide information about vertical hydraulic gradients and about the composition of single flow lines. Between 1992 and 2000, the Geological Survey of Public Works (Servicio Geológico de Obras Públicas) and the Guadalquivir Basin Authority (Confederación Hidrográfica del

\begin{tabular}{|c|c|c|c|c|}
\hline \multirow{2}{*}{$\begin{array}{c}\text { Groundwater body } \\
\text { (MASb) }\end{array}$} & \multicolumn{2}{|c|}{ PHG 2016-2021 (hm $\left.{ }^{3} / \mathbf{y}\right)$} & \multicolumn{2}{c|}{ MODFLOW model 2008-2014 } \\
\cline { 2 - 5 } & R & RD & 59.47 & 43.33 \\
\hline Almonte & 69.16 & 36.44 & 80.55 & 74.98 \\
\hline La Rocina & 80.44 & 29.29 & 62.72 & 64.45 \\
\hline Manto Eólico & 73.29 & 27.02 & 27.73 & 50.85 \\
\hline Marismas & 33.78 & 0.32 & 304.52 & 16.71 \\
\hline Marismas Doñana & 12.32 & 148.4 & & 223.31 \\
\hline TOTAL & 269 & & \\
\hline
\end{tabular}

Table 4. Estimates of total available groundwater resources in the natural regime in each MASb in the Doñana area. R: total simulated entries $\left(\mathrm{hm}^{3} / \mathrm{y}\right)$, PHG: Guadalquivir Hydrological Plan, RD: resource available for extraction according to the definition of the PHG (hm $\left.3 / \mathrm{y}\right)$. Tabla 4. Estimación de los recursos disponibles de agua subterránea en régimen natual en cada MASb del área de Doñana. R: entradas totales simuladas (hm³/año), PHG: Plan Hidrológico del Guadalquivir, RD: recurso disponible para extracción de acuerdo con el PHG $\left(h m^{3} / a \tilde{n} o\right)$. 
Guadalquivir) constructed 65 clusters with 2 to 4 piezometers of different depths per cluster. Each piezometer has a $2 \mathrm{~m}$ screen in its base. Data from these new observation boreholes provided good understanding of vertical gradients, both in the recharge and in discharge zones of the aquifer, and also about the natural composition of the groundwater, the processes controlling it, the transit time of groundwater, the existence and extent of agricultural pollution and the relationship between the different wetland types and the aquifer (Iglesias 1999; Trick and Custodio, 2004; Lozano 2004; Lozano et al. 2005; Manzano et al. 2005, 2007, 2008, 2009, 2011, 2013; Higueras 2014).

Most of the research focused on the western sandy area, which is called the Doñana Littoral Eolian Mantle (Fig. 8). With a surface area of around $400 \mathrm{~km}^{2}$ and a thickness ranging from a few metres landward and some $150 \mathrm{~m}$ on the coast, this sector is the most transmissive of the Doñana aquifer. This study is a synthesis of the knowledge and understanding gained by the authors on the groundwater natural chemical composition and contaminant processes in the Doñana Eolian Mantle aquifer sector.

Most of the groundwater samples are from single screen boreholes, a few are from multi-screened bore- holes or open wells and a few are from springs shown in Figure 9. River and lagoon samples have been taken but are not presented here. The samples were collected in double-cap polyethylene bottles. Samples for trace elements were filtered with fibreglass $0.45 \mu \mathrm{m}$ Millipore filters, acidified to $\mathrm{pH}<2$ and kept refrigerated at around $4{ }^{\circ} \mathrm{C}$ until analysis. The analyses were performed at the British Geological and Mining Institute (BGS, Wallingford, UK) and at the Geological Survey of Spain (IGME, Tres Cantos laboratory in Madrid), using standard methods. The following variables were measured: $\mathrm{Cl}, \mathrm{SO}_{4}, \mathrm{HCO}_{3}, \mathrm{NO}_{3}, \mathrm{Na}, \mathrm{K}, \mathrm{Ca}, \mathrm{Mg}, \mathrm{SiO}_{2}, \mathrm{Ba}, \mathrm{Co}$, $\mathrm{Cu}, \mathrm{Mn}, \mathrm{Sr}$ and $\mathrm{Zn}$. The following isotopes were measured: ${ }^{1{ }^{1}} \mathrm{O}_{\mathrm{H} 2 \mathrm{O}},{ }^{2} \mathrm{H}_{\mathrm{H} 2 \mathrm{O}},{ }^{3} \mathrm{H},{ }^{13} \mathrm{C},{ }^{14} \mathrm{C},{ }^{15} \mathrm{~N},{ }^{18} \mathrm{O}_{\mathrm{NO} 3},{ }^{34} \mathrm{~S}$ and ${ }^{18} \mathrm{O}_{\mathrm{SO}}$, but in this study only ${ }^{18} \mathrm{O}_{\mathrm{H} 2 \mathrm{O}}$ of the water molecule, ${ }^{15} \mathrm{~N},{ }^{18} \mathrm{O}_{\mathrm{NO}}$, ${ }^{34} \mathrm{~S}$ and ${ }^{18} \mathrm{O}_{\text {so4 }}$ are presented. All the groundwater analyses have ionic balance errors $<4 \%$. The rainwater samples have errors $<15 \%$.

The study of groundwater of chemical baseline in the Eolian Mantle was performed between 1999 and 2001 within the framework of the EU project BASELINE (https://cordis.europa.eu/project/rcn/52883_en. html), for which two specific sampling surveys were carried out and 100 samples were collected. The study of agricultural pollution was carried out between 1999 and 2013.

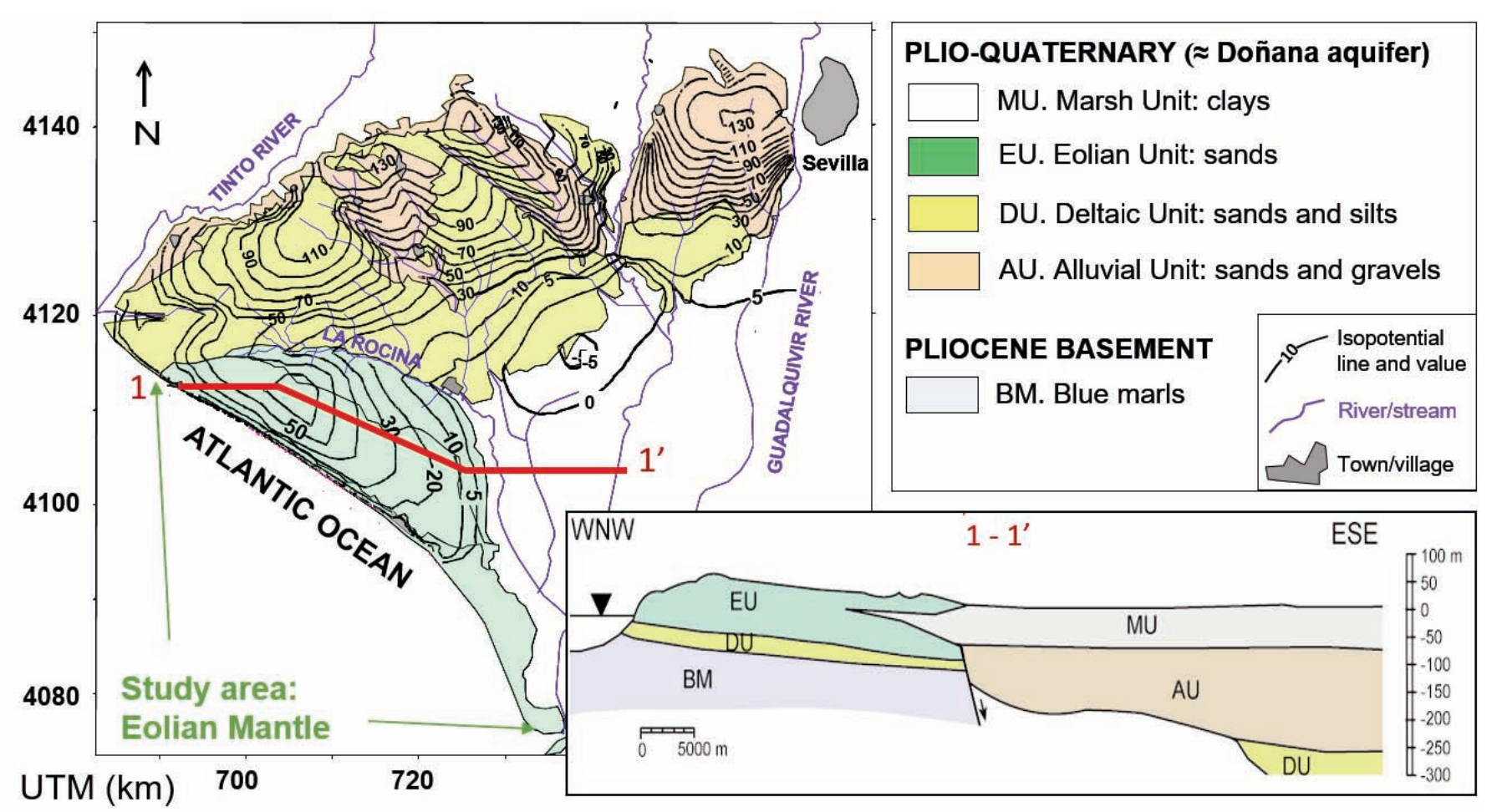

Figure 8. Location, geology and piezometry (representative of the period 1990-2000) of the studied area, the Doñana Eolian Mantle. Figura 8. Localización, geología y piezometría (representativo del periodo 1990-2000) del área de estudio, el Manto Eólico de Doñana. 


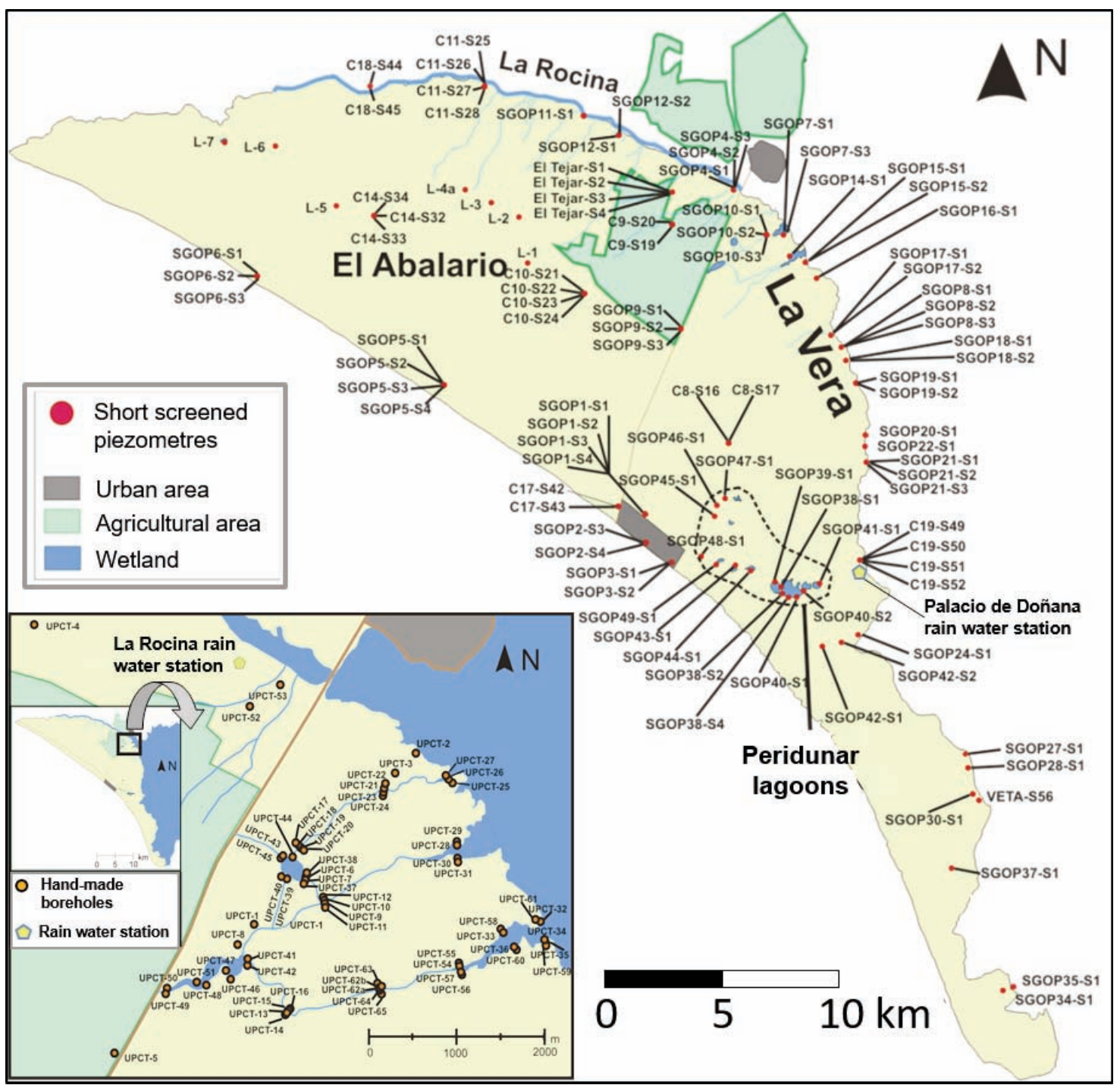

Figure 9. Location of the multi-piezometer sites sampled between 1992 and 2010 and of the rain stations sampled in periods mentioned in the text. The lower left corner shows the locations of the hand-made boreholes drilled in the 2005 Doñana project and sampled between 2006 and 2010.

Figura 9. Localización de los multi-piezómetros muestreados entre 1992 y 2010 y de las estaciones pluviométricas de los periodos mencionados en el texto. La esquina inferior izquierda muestra las localizaciones de los sondeos excavados a mano en el proyecto de Doñana del año 2005 y muestreados entre 2006 y 2010.

The methods used to evaluate the chemical and isotopic data are bivariate analyses, mass balance and hydrogeochemical modelling.

\section{Results}

Natural sources of solutes for groundwater in the Eolian Mantle Aquifer

Rainfall chemistry can be considered the minimum baseline for groundwater concentrations (Edmunds and Shand, 2009). Nonetheless, for detailed studies of groundwater genesis it is necessary to know the inter-annual rainwater composition and its regional distribution. Other natural sources of solutes are gases, organic matter and minerals present in the land surface and subsurface. Mixing with deep groundwater of different origins and chemical compositions is another source of solutes for locally recharged groundwater.

Atmospheric deposition. The expression "rainwater chemistry" is used henceforth to refer to the atmospheric deposition of solutes. It refers to the 
chemical composition of the water producing aquifer recharge, which is the result of rain composition plus the dissolution of the dust deposited on the land surface between rain events (dry deposition). Existing data on rainwater chemistry were integrated and elaborated by Higueras (2014). Because of the different sampling places and sources, one of the most adequate ways to look at the significant values is through simple statistical treatment. The 5, 25, 50, 75 and 95 percentile values of major elements and $\mathrm{pH}$ are shown in Figure 10, which illustrates the characteristic composition of rainwater at El Acebuche $(4 \mathrm{~km}$ to the sea) between 1990 and 1996, at La Rocina (20 $\mathrm{km}$ to the sea) between 2007 and 2011, and at El Palacio de Doñana (10 km to the sea) in two periods: 2000 to 2001 and 2007 to 2008.

Surprisingly for a coastal area, the rainwater is of the $\mathrm{Ca}-\mathrm{HCO}_{3}$ type and not of the $\mathrm{Na}-\mathrm{Cl}$ type, except for the rainwater collected at EI Palacio de Doñana during 2000-2001. However shallow groundwater is of the $\mathrm{Na}-\mathrm{Cl}$ type (see below), as expected. This means that the rainwater chemistry must be biased by the composition of mineral dust deposited on the surface of the collectors between rain events. This is consistent with the locations of the collectors, close to unpaved roads covered with carbonated gravels (from foreign quarries), especially the very travelled road in $\mathrm{EI}$ Palacio de Doñana. However, some useful information can be obtained from the data: i) most of the ionic ratios show that the main solute source has marine origin, which is usual in coastal areas; ii) also consistent is that the content of the most typical marine solutes $\left(\mathrm{Cl}, \mathrm{Na}, \mathrm{SO}_{4}\right)$ in atmospheric deposition decreases with increasing distance to the sea; iii) some particular rain events at El Palacio de Doñana, El Acebuche and La Rocina had a much larger $\mathrm{NO}_{3}$ content (close to $20 \mathrm{mg} / \mathrm{L}$ ) than the expected ones from an atmospheric $\mathrm{N}$ oxidation origin ( $<10 \mathrm{mg} / \mathrm{L}$ ). This is assumed to represent atmospheric pollution by (volatile) ammonium fertilizers; iv) the $\mathrm{SO}_{4} / \mathrm{Cl}$ ratio (data not shown here) shows a sulphate excess $\left(\mathrm{rSO}_{4}\right)$ $\mathrm{rCl}=0.2-0.9 ; \mathrm{r}=\mathrm{meq} / \mathrm{L}$ ) with respect to standard seawater $\left(\mathrm{rSO}_{4} / \mathrm{rCl}=0.1\right)$. A Cl mass balance between rainwater and shallow (phreatic) groundwater shows that only about $30 \%$ of $\mathrm{SO}_{4}$ in rainwater can be accounted for as being of a marine origin. In areas without agricultural influence, the rest $(70 \%)$ may be partly attributed to the atmospheric supply of sulphide particles, most probably from the SW of the aquifer, which is the dominant wind direction. The proposed original source for these particles is either industrial emissions from the Huelva industrial site, situated some $30 \mathrm{~km}$ to the NW, and/or open-pit mining activities in the numerous sulphide mines of the Iberian Pyrite Belt, which crops out to the N and NW of Doñana. An isotopic study $\left({ }^{34} \mathrm{~S}\right)$ performed in the 2000s gave insight into this subject (see below).

Lithological sources. The mineralogy of the Eolian
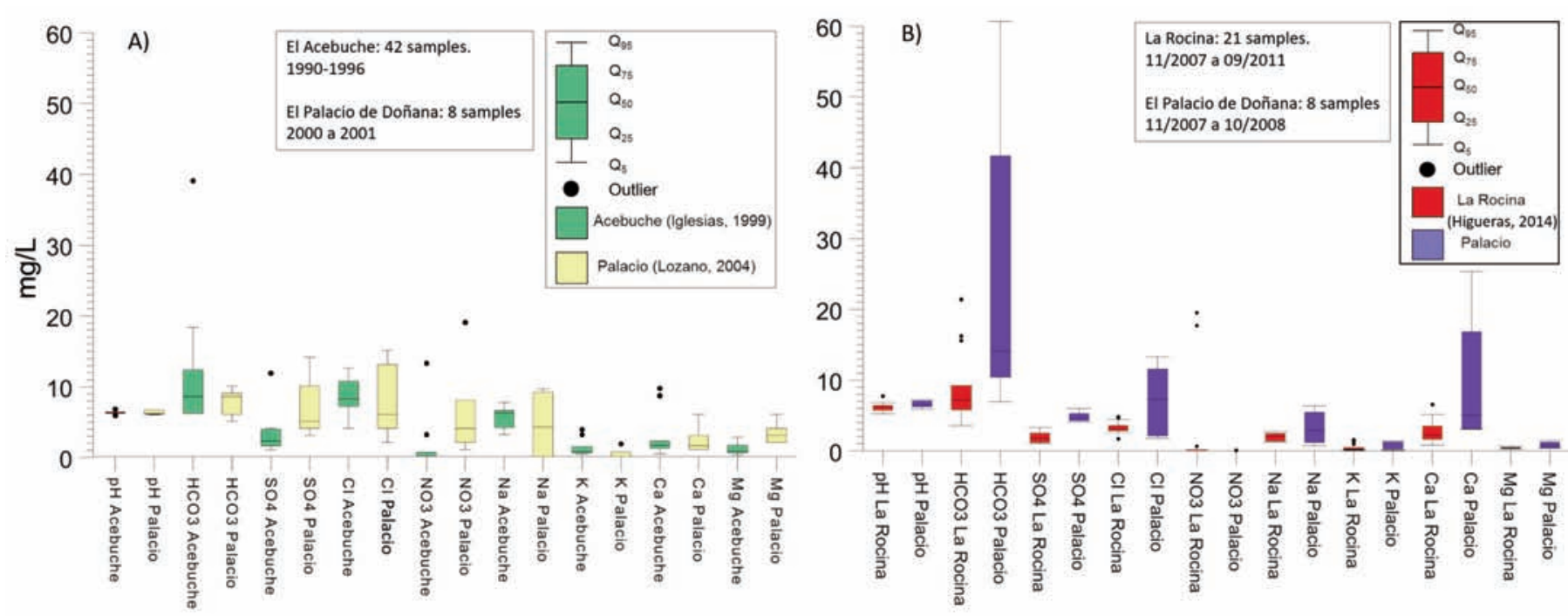

Figure 10. Box plots of the chemical composition of rainwater sampled at El Acebuche, El Palacio de Doñana and La Rocina in the indicated periods. A) Data from Iglesias (1999) and Lozano (2004). B) Data modified from Higueras (2014).

Figura 10. Diagramas de caja de la composición química del agua muestreada en El Acebuche, El Palacio de Doñana y La Rocina en los periodos indicados. A) Datos de Iglesias (1999) y Lozano (2004). B) Datos modificados de Higueras (2014). 
Mantle is dominated by silicates (Iglesias 1999; Higueras 2014). Amorphous silica is the most abundant mineral, followed by quartz, K-feldspar (microcline), Na-feldspar (albite) and muscovite. Clay minerals consist of illite, chlorite, kaolinite, montmorillonite and vermiculite, but they are minor components. Carbonates, mostly $\mathrm{CaCO}_{3}$, are present either as detrital grains or as shell remains but on a sub-regional scale. They are absent in the uppermost and middledepth layers of the central part of the Eolian Mantle, most probably because they have been leached by rainfall infiltration throughout time. Trace concentrations of halite are present in the shallowest samples, and particularly close to soil depressions. This can be explained by intense evapotranspiration of soil water, shallow water-tables and lagoon water.

Potential pollution sources. Most of the surface of the Eolian Mantle is a rural area, with a notable part devoted to agriculture (strawberries and blackberries), some urban settlements (El Rocío village, to the $\mathrm{NE}$; Matalascañas and Mazagón beach resorts, to the SE and SW, several heavily transited roads (EI RocíoMatalascañas-Moguer) and also wild areas. From the middle of the 1970 s to the early 2000 s the use of synthetic fertilizers was probably the main local polluting activity. Though most of the sewer network has been developed in the last 20-30 years, it is not expected that wastewater dating before the existence of network and treatment plants remains in the aquifer. Gases and particles (metals, hydrocarbons) from engine combustion in the frequently crowded routes crossing the aquifer to the shoreline are probably the second major source of pollution. Finally, the area is located $15-30 \mathrm{~km}$ to the $E$ of the large Huelva city industrial area, where intense polluting activities, such as pyrite burning and oil refining, have been carried out during decades in the 20th century (oil refining is still active, but nowadays it is a less polluting activity). Then, agricultural, urban and industrial pollution sources are abundant, yet localized, in the recharge areas of the aquifer.

\section{Groundwater natural composition and geochemical controls in the Eolian Mantle Aquifer}

The chemical analyses performed in the shortscreened boreholes shown in Figure 9 between 1992 and 2010 showed very small, if any, temporal changes during this period for the major part of the locations. There were two exceptions: i) in a few shallow boreholes located near wetlands groundwater mineralization was increasing and the chemical facies was changing from $\mathrm{Na}-\mathrm{Cl}$ to $\mathrm{Ca}-\mathrm{SO}_{4}$ (see discussion below); ii) the samples from a few short-screened boreholes drilled during 1992 to 2000 were imprinted by the remnants (in the aquifer) of a Na polymer used during drilling. Natural dilution of these remnants was very slow due to the small permeability and hydraulic gradients. During several years, sampling these boreholes was always preceded by pumping until $\mathrm{pH}$ and EC stabilized in values consistent with those of the unpolluted boreholes.

In the early studies it was observed that both the chemical and the hydrogeological characteristics of the upper part (down to $35-40 \mathrm{~m}$ ) of the Eolian Unit are somewhat different to those of the lower part (roughly $>40 \mathrm{~m}$ ). This can be defined as two subunits, the Upper Eolian Unit and the Lower Eolian Unit (Iglesias, 1999). In the central part of the Eolian Unit, groundwater is of the $\mathrm{Na}-\mathrm{Cl}$ type and lowly mineralized $\left(E C \leq 0.5 \mathrm{mS} \mathrm{cm}^{-1}\right)$ in the Upper Eolian Unit (Figure $11 \mathrm{~A}$ ) and $\mathrm{NaCa}-\mathrm{ClHCO}_{3}$ or $\mathrm{Ca}-\mathrm{HCO}_{3}$ in the Lower Eolian Unit (Fig. 11B). The composition of the $\mathrm{Na}-\mathrm{Cl}$ waters is the result of slightly evaporated rainwater infiltrating and dissolving soil $\mathrm{CO}_{2}$ and $\mathrm{Na} / \mathrm{K}$ feldspars, accompanied by cation exchange. The other chemical facies are the result of $\mathrm{Na}-\mathrm{Cl}$ water type dissolving $\mathrm{CaCO}_{3}$ in the deepest layers of the Eolian Unit (Iglesias 1999; Lozano et al. 2005; Manzano et al. 2008).

Along the $\mathrm{N}$ and NE border of both sub-units, the groundwater has similar chemical facies as the centre of the Eolian Unit. This is consistent with the hydrodynamic model, as these zones are discharge areas of groundwater recharged in the central part of the Eolian Unit. To the NW of both sub-units there are two particular piezometric clusters ( $\mathrm{C} 11$ and $\mathrm{C} 18$ ) with $\mathrm{Na}$ $\mathrm{Cl}$ type and quite mineralized $\left(\mathrm{EC} \approx 1-3.5 \mathrm{mS} \mathrm{cm}^{-1}\right.$ ) water in all their piezometers, whatever their depth. These piezometers are drilled in low permeability sediments of the Rocina creek flooding zone and are quite difficult to regenerate by pumping. They are periodically flooded, and following the information provided by the stable isotopes (not shown here) the water inside the casings is notably concentrated by evaporation and some salt dissolution cannot be excluded.

To the SE border of the Upper Eolian Unit, the groundwater is also of the $\mathrm{Na}-\mathrm{Cl}$ type and the mineralization reaches $80 \mathrm{mS} \mathrm{cm}^{-1}$ (Fig. 11A). This is attributed to the mixing of fresh groundwater recharged in the Upper Eolian Unit with marine groundwater intruded both in the clays of the Marsh Unit and in the gravels confined under the clays. The mixing is accompanied by cation exchange with $\mathrm{Na}$ uptake and Ca release.

Some shallow groundwater samples from the 
Upper Eolian Unit collected around the peridunar lagoons have a $\mathrm{NaCaMgSO}_{4}$ facies (e.g. sample SGOP45-S1 in Fig. 11A). After chemical, isotopic and hydrodynamic modelling studies (Lozano 2004, Lozano et al. 2005; Manzano et al. 2005, 2007, 2013), this was attributed to recent changes in the wetland hydrology as a result of intensive groundwater pumping in the Eolian Mantle since the mid 1970s. Accumulated inter-annual lowering of the piezometric levels of deep aquifer layers, the preferentially exploited ones, induced a progressive water-table drawdown which reduced the rates of discharge through seepage and phreatic evapotranspiration and modified wetland hydro-period and water and solute balances. Some formerly peridunar flowthrough wetlands are nowadays disconnected from the water table for most of the year or permanently. Thus, their sediments become salt traps of $\mathrm{Cl}, \mathrm{Na}, \mathrm{Ca}$, $\mathrm{C}$, and mostly $\mathrm{S}$ and act as a salt source during rain events for the shallow groundwater around the wetland basins. As the dissolution and evacuation of salt from the wetland sediments is partial, local ground- water is expected to become progressively more saline.

The chemical cross section shown in Figure 12A is representative, in general terms, of the groundwater evolution along the main flow paths at a wider scale in the Doñana aquifer outside the Eolian Unit. In the water-table area to the $\mathrm{N}$ of the marshes, where the aquifer is thinner $(<50 \mathrm{~m})$ and consists of silts and siliceous and carbonate silty sands, the groundwater is of the $\mathrm{Ca}-\mathrm{HCO}_{3}$ or $\mathrm{NaCa}-\mathrm{HCO}_{3} \mathrm{Cl}$ types, but as it reaches the area confined under the marshes it evolves rapidly to a $\mathrm{Na}-\mathrm{Cl}$ type and becomes brackish and finally saline due to mixing with seawater existing under the marshes.

Figure 12B shows box plots of groundwater in the Upper and Lower Eolian Unit using data from around 100 samples collected between 1999 and 2000 for the BASELINE project. The statistical values of $\mathrm{pH}$ and solutes show that the natural groundwater chemistry is very similar in both sub-units, except for $\mathrm{Ca}$ and $\mathrm{HCO}_{3}$, whose contents are larger in the Lower Unit in coherence with the major presence of $\mathrm{CaCO}_{3}$ in the

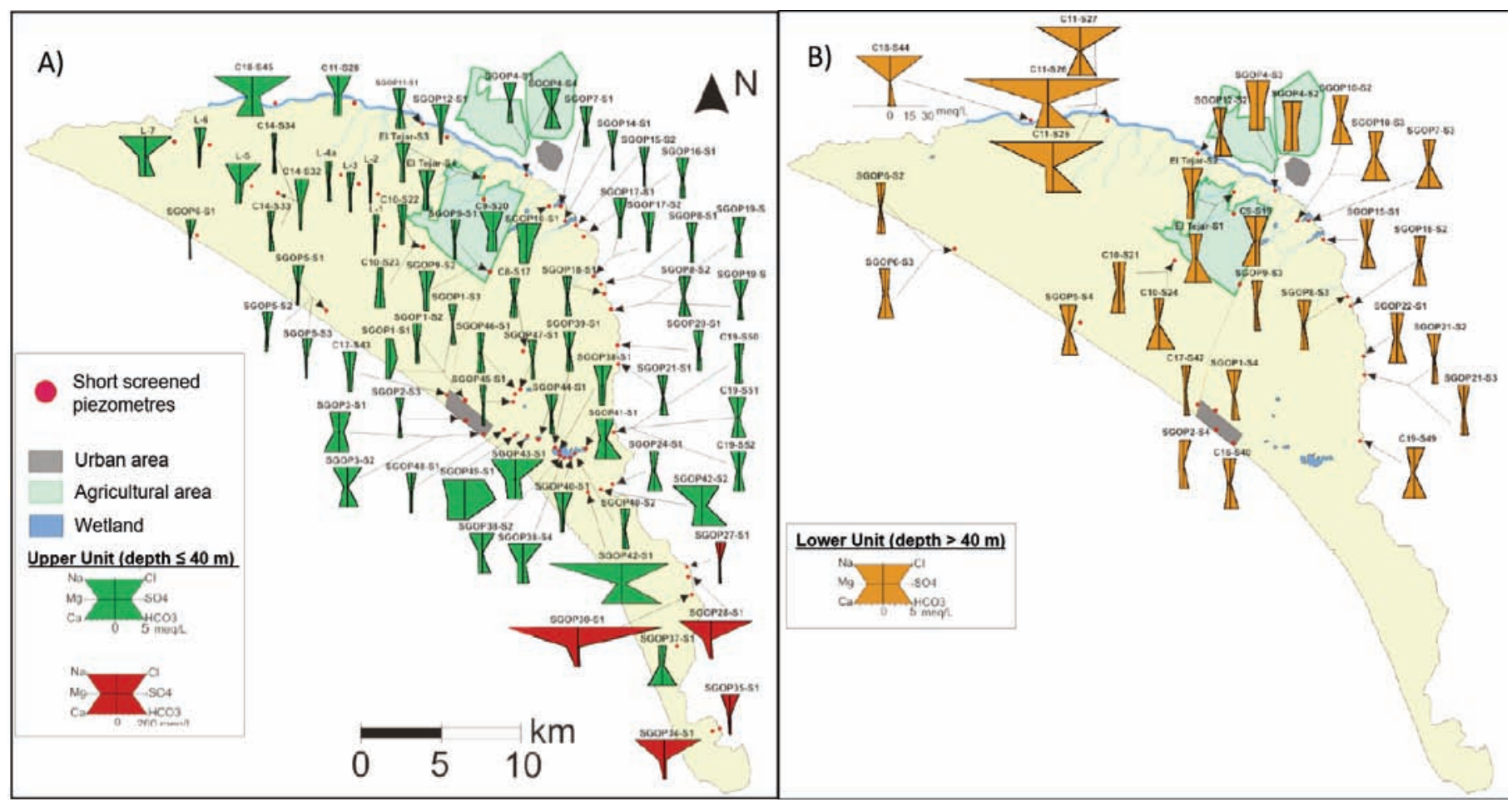

Figure 11. A) Modified Stiff diagrams of groundwater samples in the Upper Eolian Unit. B) Modified Stiff diagrams in the Lower Eolian Unit. Each diagram shows the average composition of 5 to 20 different analyses performed at each piezometer between 1995 and 2009 . Modified from Higueras (2014).

Figura 11. A) Diagramas modificados de Stiff de las muestras de agua subterránea de la Unidad Eólica Superior. B) Diagramas modificados de Stiff de las muestras de agua subterránea de la Unidad Eólica Inferior. Cada diagrama muestra la media composicional de 5 a 20 análisis diferentes realizados en cada piezómetro entre 1995 y 2009. Modificado de Higueras (2014). 
lower layers of the Eolian Unit. The main difference is shown by a set of solutes whose presence in groundwater can have both natural and anthropic origins. $\mathrm{NO}_{3}, \mathrm{SO}_{4}, \mathrm{Co}, \mathrm{Cu}$ and $\mathrm{Zn}$ show larger contents in the Upper Eolian Unit, which was assumed to represent pollution of shallow groundwater by fertilizers.

\section{Groundwater pollution by agricultural practices}

The results of the BASELINE project gave rise to a study on the extent and mechanisms of groundwater pollution by agrochemicals in the Eolian Mantle aquifer. The study focused firstly in $\mathrm{SO}_{4}$ (2000-2001) and was later extended to $\mathrm{NO}_{3}(2008-2010)$.

$\mathrm{NO}_{3}$ and $\mathrm{SO}_{4}$ contents in groundwater samples collected at different depths in springs, shallow handmade wells and single-screen boreholes in several years between 1992 and 2010 are shown in Figure 13. All the sites with less than $90 \mathrm{~m}$ depth were sampled several times, and those deeper than $10 \mathrm{~m}$ had very constant $\mathrm{SO}_{4}$ and $\mathrm{NO}_{3}$ contents. On the other hand, the largest concentrations of both solutes were observed in the uppermost $25-30 \mathrm{~m}$ of aquifer during the entire period. Two hypotheses were proposed, explaining that this depth represents i) the downward moving front of the infiltrating polluted groundwater or ii) the position of a reduction front. An isotopic study was performed to check both hypotheses.

The relationship between $\delta^{18} \mathrm{O}$ of dissolved $\mathrm{SO}_{4}$ and $\delta^{18} \mathrm{O}$ of the water molecule discards the atmospheric supply of sulphide particles from the Iberian Pyrite-Belt as a source of $\mathrm{SO}_{4}$ in local recharge water (Fig. 14A). On the other hand, Figure 14B shows that the main sources of $\mathrm{SO}_{4}$ in groundwater are marineborne aerosol, whose proportion in recharge water varies with the distance to the sea and fertilizers. This figure also shows that many samples have less $\mathrm{SO}_{4}$ than expected, due to sulphate reduction. Reduction processes affect samples taken at all depths (both above and below the hypothetical reduction front at 25-30 m) and in many locations, but especially close to some creeks and lagoons. Thus, reduction is not the cause of the observed sulphate front at 25-30 m depth.

Figure 15A shows that ammonia fertilizers seem to be a main source of $\mathrm{NO}_{3}$ in the shallow groundwater of the Mimbrales-La Vera sector in the Eolian Mantle. Ammonia fertilizers also contribute to the atmospheric source or recharge, represented by samples L2 and

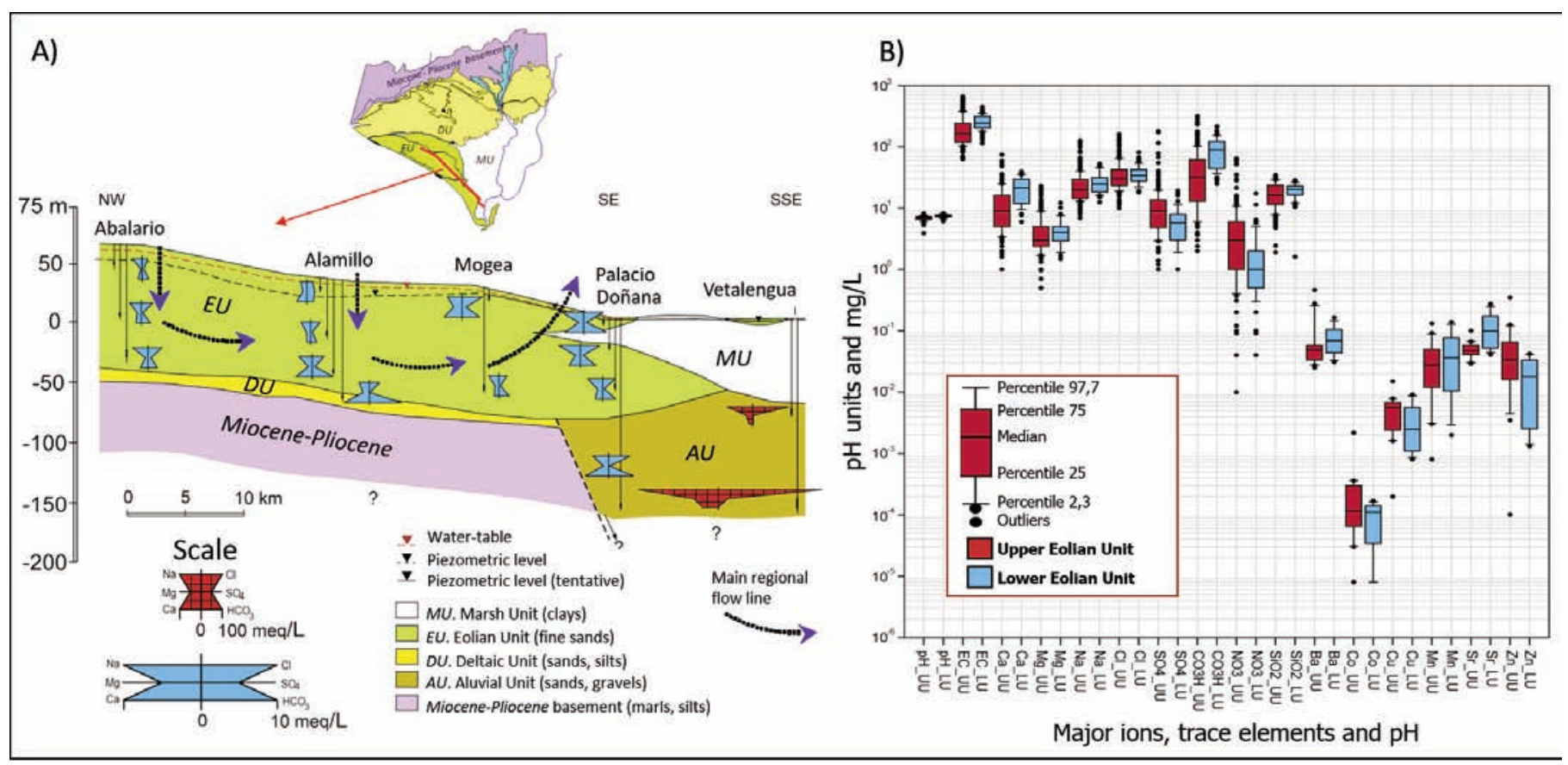

Figure 12. A) Representative hydrochemical cross section in the Eolian Unit. B) Box plot of groundwater chemistry in the Upper Eolian Unit and the Lower Eolian Unit performed with 100 samples collected in 1999 and 2000. Modified after Manzano et al. (2005, 2008).

Figura 12. A) Corte hidroquímico representativo de la Unidad Eólica. B) Diagrama de caja de la química del agua subterránea de la Unidad Eólica Superior e Inferior de 100 muestras recogidas entre 1999 y 2000. Modificado de Manzano et al. (2005, 2008). 


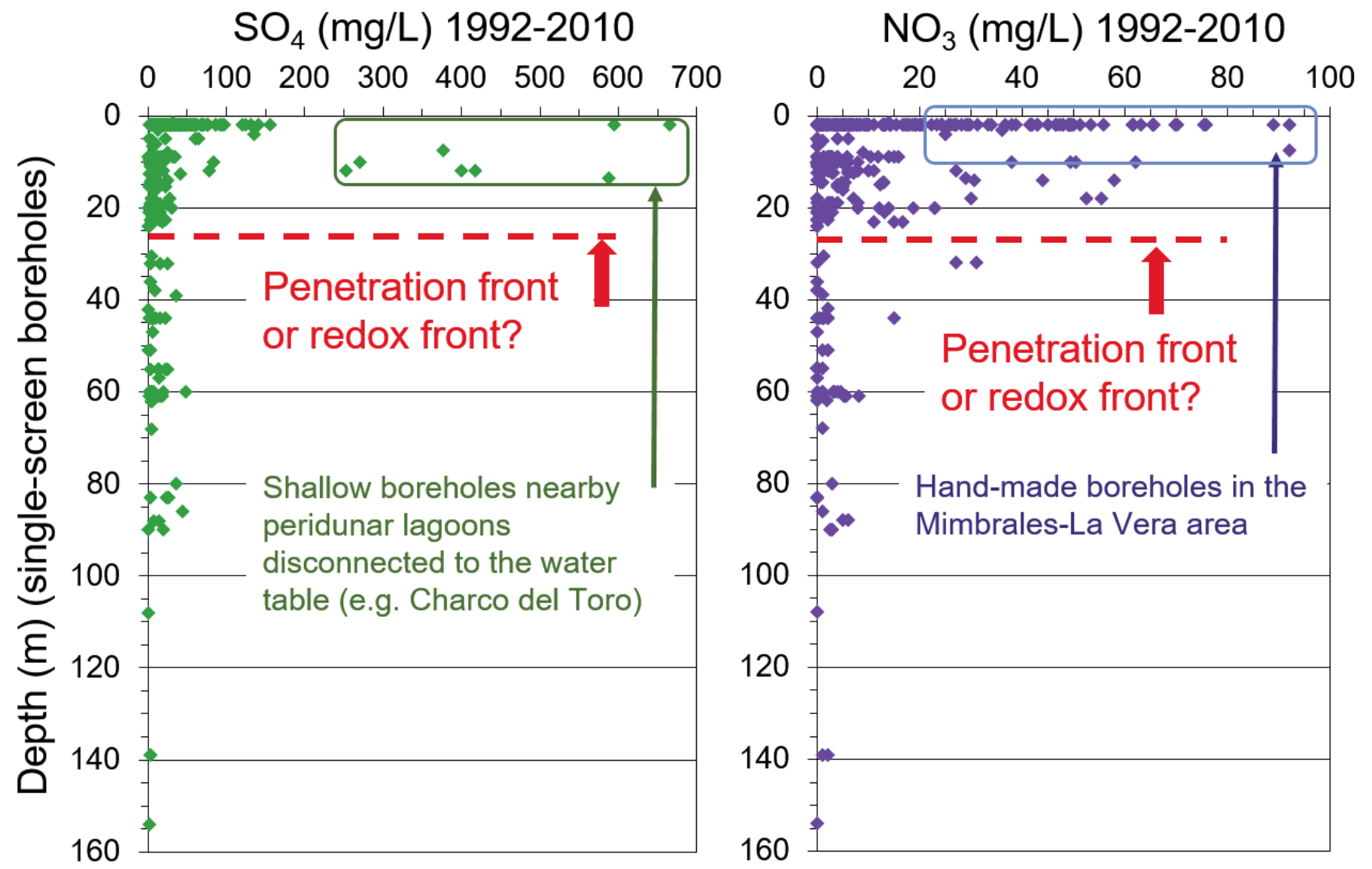

Figure 13. A) Sulphate contents measured in samples taken at different depths in single-screen boreholes between 1992 and 2010 . B) Nitrate contents measured in the same samples.

Figura 13. A) Contenidos de sulfato medidos en muestras recogidas a diferentes profundidades en sondeos entre 1992 y 2010 . B) Contenidos de nitrato medidos en las mismas muestras.

$75^{\prime}$ (from boreholes located outside the influence of the agricultural area). This figure suggests that many groundwater samples, as well as the two excess irrigation water samples AC and DS, taken in open-air channels, are isotopically enriched by denitrification. Figure 15B shows that most of the shallow groundwater in the Mimbrales-La Vera area has its $\mathrm{NO}_{3}$ from a mixture of the two sources identified, atmospheric supply (represented by samples L2 and 75') and fertilizers (represented by the excess irrigation samples $A C$ and DS). However, only a few groundwater samples seem to be affected by denitrification in the aquifer. The isotopic composition of the excess irrigation samples suggests that denitrification occurs significantly during infiltration, and that when agrochemical $\mathrm{NO}_{3}$ reaches groundwater, it is already enriched by this process.

A nested borehole with four small diameter tubes was drilled in 1995 in the middle of the strawberry field of El Tejar, shortly after cultivation ceased, to study the transport of agrochemicals in the uppermost $22 \mathrm{~m}$ of the aquifer (Figure 16).

Ten sampling surveys were performed between February 1995 and March 2009. The contents of $\mathrm{NO}_{3}$ did not change significantly at each borehole/depth during the fourteen years. Nitrate contents decreased downwards, from several tens of $\mathrm{mg} / \mathrm{L}$ at $10 \mathrm{~m}$ depth to $<5 \mathrm{mg} / \mathrm{L}$ at $22 \mathrm{~m}$ depth, during the entire period (Fig. 16A). This behaviour is consistent with that shown in Figure 13. Moreover, it means that after more than ten years without cultivation, there was still a significant mass of $\mathrm{NO}_{3}$ in the shallowest layers of the terrain. The $\delta^{15} \mathrm{~N}$ values of the samples collected in 2009 are consistent with a manure origin, which was the last type of fertilizer used in the zone, but their vertical distribution is not consistent with the existence of a reduction front at around $25 \mathrm{~m}$ (Fig. 16B). This results rejects the hypothesis of the reduction front and builds 

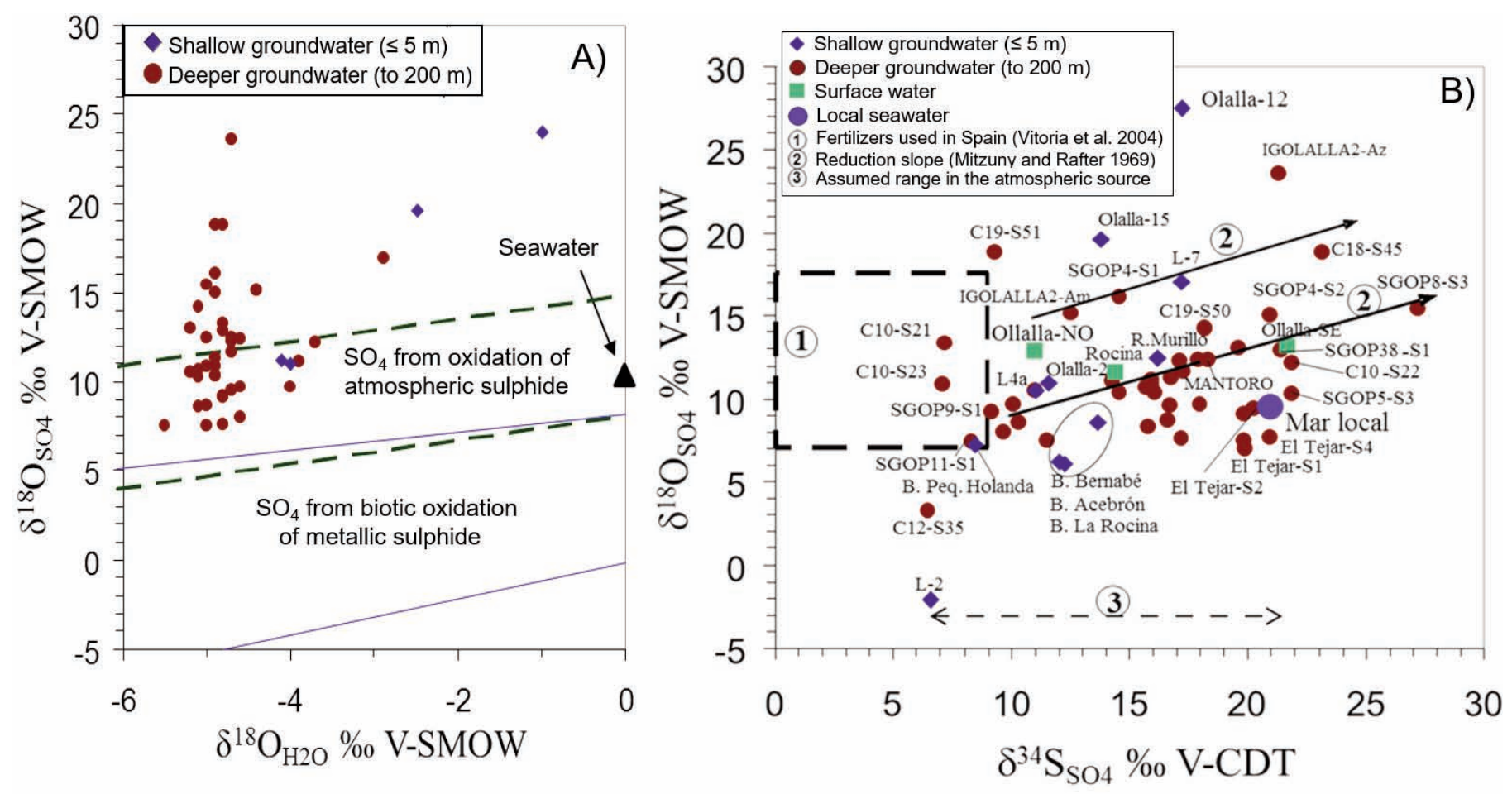

Figure 14. Identification of $\mathrm{SO}_{4}$ sources and modification processes in groundwater of the Eolian Mantle. A) A main source is seawater aerosol; metallic sulphides are not a source. B) Fertilizers are the second main source of $\mathrm{SO}_{4}$. Many samples have less $\mathrm{SO}_{4}$ than expected from whatever source due to reduction processes. Modified from Manzano et al. (2011). V-CDT means Vienna-Canyon Diablo Troilite standard.

Figura 14. Identificación de las fuentes de $\mathrm{SO}_{4}$ y procesos de modificación en las aguas subterráneas del Manto Eólico. A) La principal fuente es el aerosol de las aguas marinas; los sulfuros metálicos no son una fuente. B) Los fertilizantes son la segunda Fuente principal de $\mathrm{SO}_{4}$. Muchas de las muestras contienen menos $\mathrm{SO}_{4}$ de lo esperado debido a los procesos de reducción. Modificado de Manzano et al. (2011). V-CDT es el acrónimo de Vienna-Canyon Diablo Troilite estandar.

up a new one: the distribution of nitrate (and sulphate) observed in the upper part of the aquifer could be the result of the dominance of lateral flow in this zone, instead of the vertical flow assumed up to now.

To investigate the origin of the elevated concentrations of arsenic (As) which had been detected in 2008 during the exploration of the water supply for the Marismillas Palace (Fig. 1), a further study was conducted in 2012 and 2013 (Kohfahl et al., 2016). At a larger scale, 13 piezometers and surface water samples from about 50 artificial drinking ponds and freshwater lagoons throughout the National Park were collected and analysed for major ions, metals and trace elements. At a smaller scale, 5 locations were equipped with piezometers and groundwater was sampled up to 4 times for ambient parameters, major ions, metals, trace elements and iron (Fe) speciation. As was analysed for inorganic and organic speciation. Undisturbed sediment samples were analysed for physical parameters, mineralogy, geochemistry as well as As species. Sediment analyses yielded total As between 0.1 and $18 \mathrm{mg} / \mathrm{kg}$ and are not correlated with As concentration in water. Results of the surface- and groundwater sampling revealed elevated concentration of As up to $302 \mathrm{~g} / \mathrm{L}$ within a restricted area of the National Park, close to the Marismillas Palace (Fig. 1). Results of the groundwater sampling indicated a strong correlation of $\mathrm{As}$ with $\mathrm{Fe}^{2+}$, pointing to As mobilisation due to reductive dissolution of hydroferric oxides (HFO) in areas of locally elevated amounts of organic matter within the sediments. High As concentrations in surface water ponds are correlated with elevated alkalinity and $\mathrm{pH}$ attributed to algae metabolism, leading to As desorption from HFO. The algae metabolism is responsible for the presence of methylated arsenic species in surface water, in contrast to groundwater in which only inorganic As species was found. Temporal variations in surface water and groundwater are also related to changes in $\mathrm{pH}$ and alkalinity as a result of enhanced algae metabolism in 

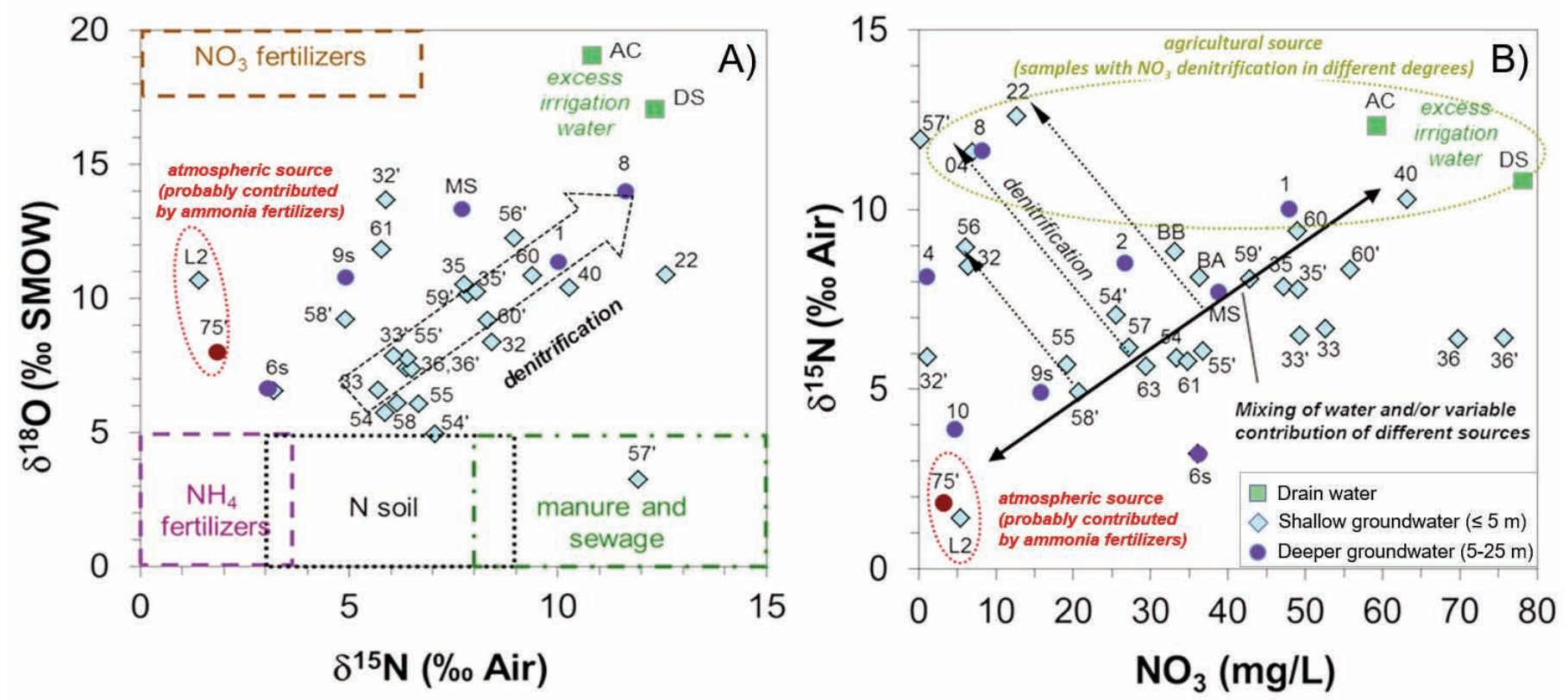

Figure 15. Identification of $\mathrm{NO}_{3}$ sources and modification processes in shallow groundwater of the Mimbrales-La Vera sector in the Eolian Mantle. A) Ammonia fertilizers seem to be a main source of $\mathrm{NO}_{3}$ in groundwater and in the atmospheric source. Many groundwater samples seem to be isotopically enriched by denitrification. Also the excess irrigation water samples are isotopically enriched by denitrification. B) Most of the groundwater samples have their $\mathrm{NO}_{3}$ from a mixture of atmospheric supply and fertilizers. A few groundwater samples seem to be affected by denitrification in the aquifer, but denitrification seems to occur mainly during the infiltration of irrigation water. Modified from Manzano et al. (2011).

Figura 15. Identificación de las fuentes de $\mathrm{NO}_{3}$ y procesos de modificación en las aguas subterráneas cercanas a la superficie en el Manto Eólico del sector de Los Mimbrales - La Vera. A) Los fertilizantes con amonio parecen ser la fuente principal de NO3 en agua subterránea y en la fuente atmosférica. Muchas muestras de agua subterránea parecen estar enriquecidas isotópicamente por desnitrificación. También, las muestras de excedentes de agua de riego se enriquecen isotópicamente por desnitrificación. B) Muchas de las muestras de agua subterránea contienen $\mathrm{NO}_{3}$ de la mezcla de fuente atmosférica y fertilizantes. Algunas muestras de agua subterránea parecen afectadas por la desnitrificación en el acuífero, pero la denitrificación parece ocurrir principalmente durante la infiltración de los retornos de riego. Modificado de Manzano et al. (2011).

surface water or related to changes in the redox level in the case of groundwater.

\section{Active monitoring network for recharge measurements in the Doñana National Park}

Over the last decade, an extensive amount of research has been published on how climate change might influence different aspects of the hydrological cycle (Burns et al., 2007; Hagg et al., 2007 amongst others). Despite the increasing amount of literature on the impact on groundwater (Green et al., 2007), as far as the authors are aware, there is limited information on the impact on groundwater dependent ecosystems derived from a combination of climate change and management scenarios (Risbey et al., 2007).

The starting hypothesis is that in semiarid areas groundwater recharge will probably be subjected to a significant reduction in the near future due to climate change and intensive human activities such as agriculture and tourism leading to important social economic but also ecological hazards for the society. This is especially relevant for regions with elevated water demands in close vicinity to sensitive ecosystems such as the groundwater dependent wetland of the Doñana National Park which is delimited by a belt of intensive agricultural activity and tourism. Groundwater recharge is a complex process and highly dependent on meteorological, hydrological and geological parameters which are normally not measured and therefore recharge estimations normally rely on rough estimates making it impossible to plan a sound and sustainable management of water resources to meet long-term social economic and ecologic demands.

The overall aim of the monitoring network is to study the impact of climate change on groundwater resources in wetlands in general, based on the exam- 


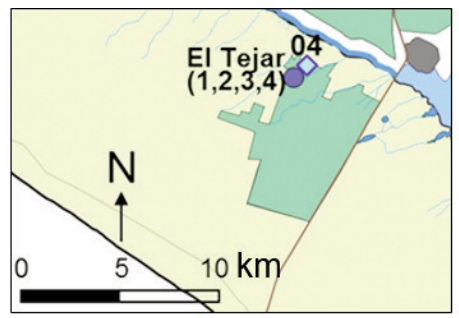

El Tejar nested borehole

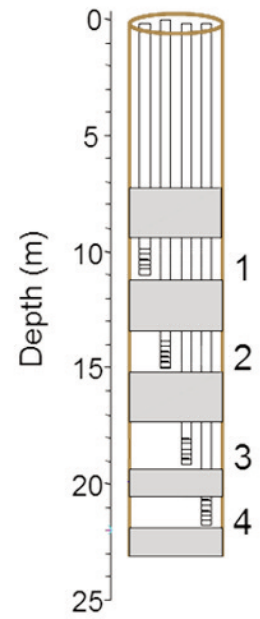

A) $\quad \mathrm{NO}_{3}(\mathrm{mg} / \mathrm{L})$

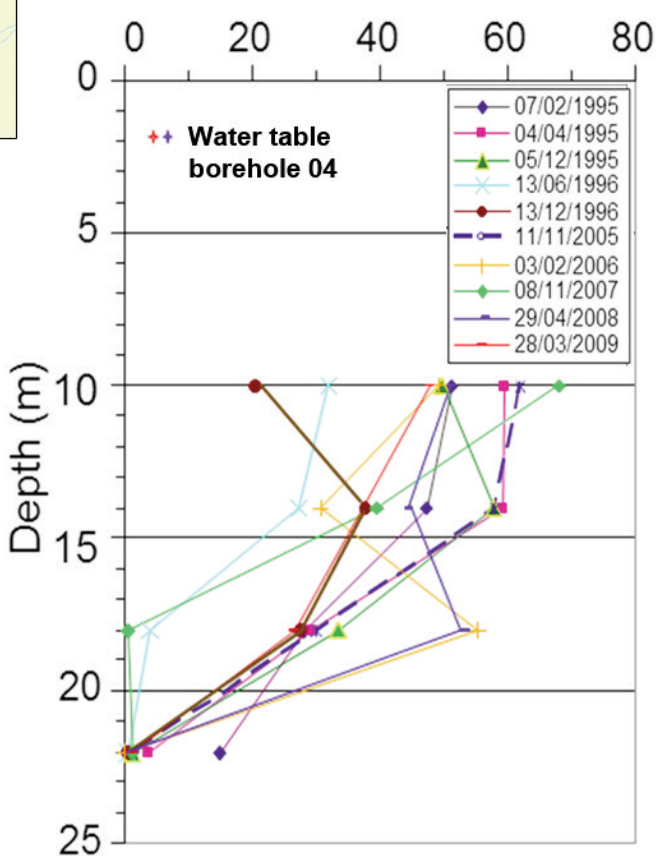

B) $\quad \mathrm{NO}_{3}(\mathrm{mg} / \mathrm{L}) \& \delta^{15} \mathrm{~N}(\%$ air $)$

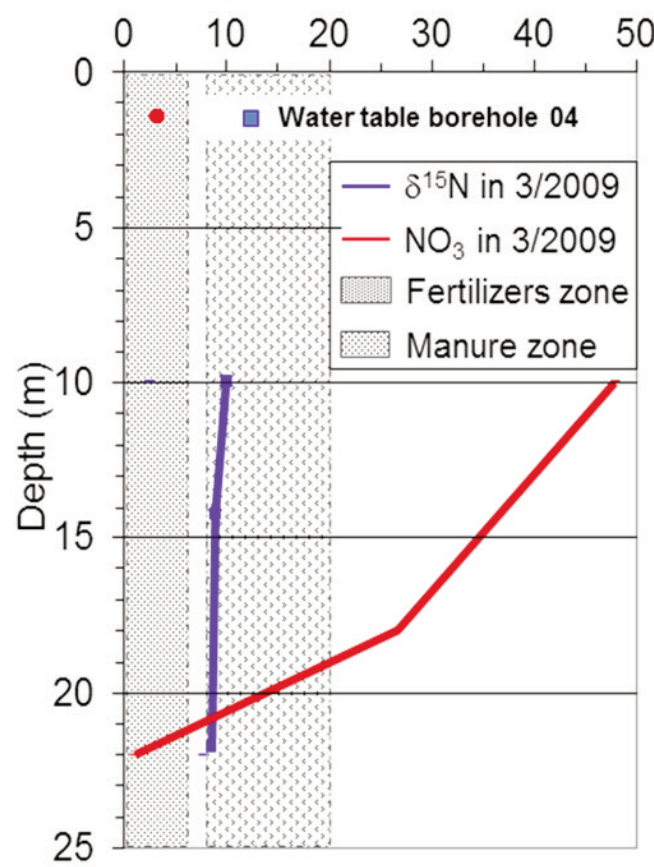

Figure 16. A) Nitrate contents between 1995 and 2009 in a nested borehole drilled in a cultivation field in 1995, shortly before cultivation ceased. B) Isotopic values of dissolved $\mathrm{NO}_{3}$ in 2009, after more than ten years without cultivation. Modified from Manzano et al. (2011).

Figura 16. A) Contenidos de nitrato entre 1995 y 2009 en un sondeo de una zona de cultivo en 1995, muy poco después de cesar las labores de cultivo. B) Valores de $\mathrm{NO}_{3}$ disuelto en 2009, tras diez años sin cultivo. Modificado de Manzano et al. (2011).

ple of the Doñana National Park. The main objectives to match this aim are the determination of groundwater recharge and vapour flow and their dependence on meteorological, hydrogeological and soil parameters using a weighing precision meteo lysimeter and humidity and piezometric sensors installed at different locations.

\section{Methods}

The total infrastructure consists of one high precision meteo-lysimeter and further measurements of meteorological parameters, soil parameters as well as groundwater levels, electric conductivity and temperature in different sites, as shown in Figure 17 and Table 5.

The following measurements were performed as indicated in Table 6.

The meteo-lysimeter site is equipped with a UMS (UMS AG, Munich, Germany) weighing lysimeter (1 $\mathrm{m}^{2}$ surface, $1.50 \mathrm{~m}$ height and a weighing resolution of $10 \mathrm{~g}$ ), 2 automatic meteorological stations (Vantage PRO2 Davis, California, USA; UMS AG, Munich, Germany) and a weighing pluviometer (OTT, Hellmann). The lower boundary at the bottom of the lysimeter is controlled using 2 tensiometers installed inside and outside of the lysimeter at $1.4 \mathrm{~m}$ depth. A bidirectional peristaltic pump maintains the bottom of the lysimeter at the same humidity as measured by the field tensiometer installed outside the lysimeter. The surface of the lysimeter was always maintained free of vegetation. Rain and drained water from the lysimeter was collected and sampled for analysis of stable isotopes and mayor ions. Furthermore, six CS650 soil moisture sensors (Campbell Scientific, Logan, UT) were installed beside the lysimeter at $0.30,0.60,1.20,1.60,2.20$, and $3 \mathrm{~m}$ depth.

Installation of humidity sensors in the respective depths was carried out at all sites by horizontal introduction into the natural undisturbed sediment after pit excavation. Soil moisture at the Santa Olalla Site was also measured with CS650 soil moisture sensors, whereas at the Marismillas site the measurements 


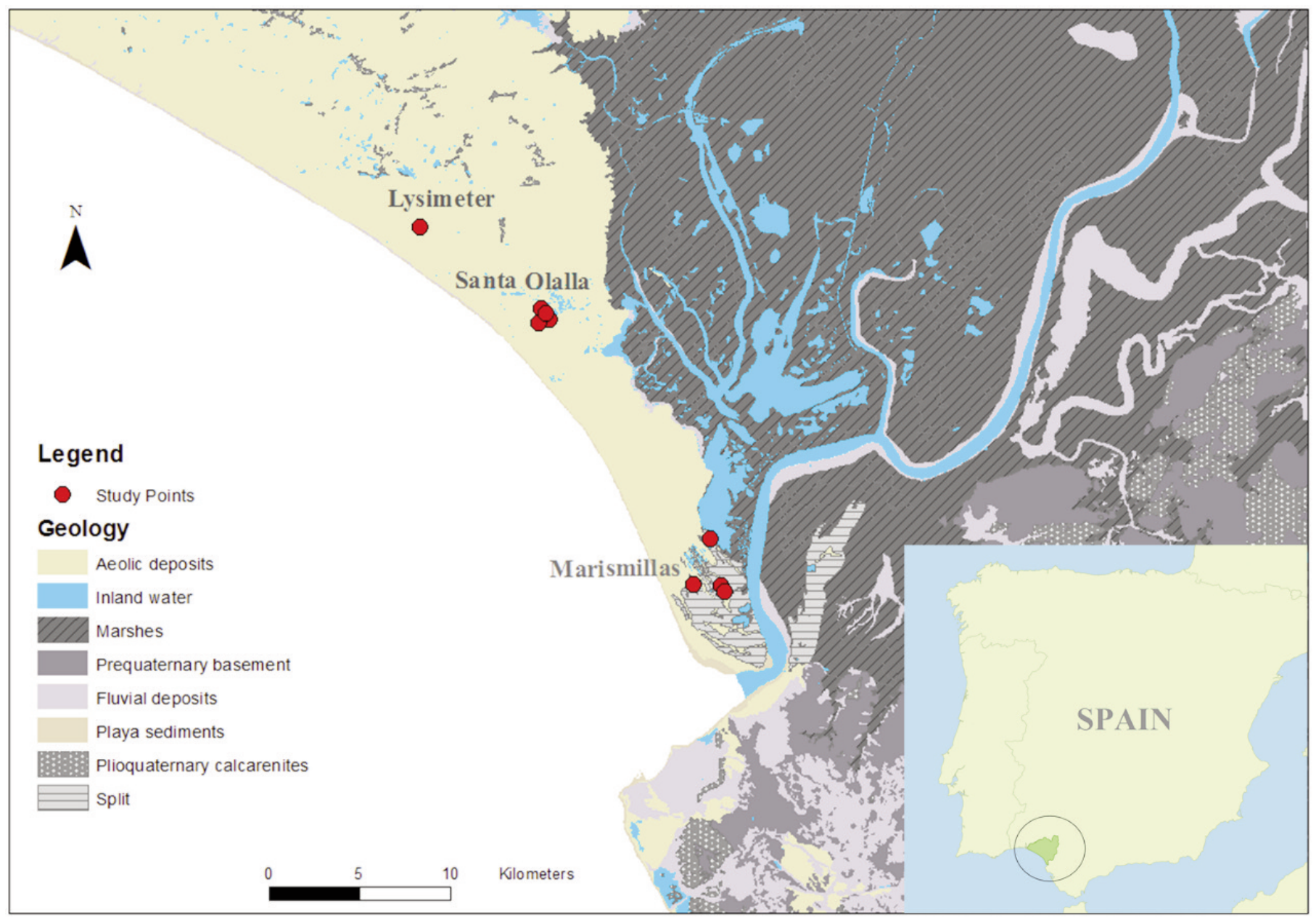

Figure 17. Study sites and locations of the monitoring network.

Figura 17. Zonas de estudio y localización de las redes de monitoreo.

were made with GS3 sensors (Decagon Devices). For groundwater sampling and monitoring, $5 \mathrm{~cm}$ diameter HDPE piezometers were installed manually with a jack hammer and soil samples were taken with transparent methacrylate liners, steel cylinders and plastic bags and were stored at $4{ }^{\circ} \mathrm{C}$ in the IGME laboratory for subsequent analysis. Physico-chemical soil properties such as density, grain size distribution, mineralogy and metals were also analysed at different depths.

To filter measurement noise, the raw data from lysimeter and drainage vessel weight were corrected to accurately calculate precipitation $(P)$ and recharge (R). The time-series of lysimeter weight and drainage water quantity can be affected by a wide variety of singular disturbances, which add to the measurement noise. Examples are the withdrawal of water from the drainage sampling vessel, sudden changes in weight when vegetation is removed, maintenance work, and technical staff stepping on the lysimeter surface, and so on. Detection and correction of such singular events was performed by suitable filters and manually in some cases.

Intrinsic noise of lysimeter raw data was reduced by smoothing through the AWAT filter (Peters et al. 2014). This method has recently been applied in other studies (Hoffmann et al., 2016).

According to the soil water balance, the infiltrating rain water, $\mathrm{P}$, increases soil water storage ( $\Delta$ wlys) and recharge $(R)$, assuming that no evapotranspiration (ET) occurs during rainfall. The hydrological balance equation states that:

$$
\mathrm{P}=\mathrm{R}+\mathrm{ET}+\Delta \text { wlys }
$$

$\mathrm{P}$ and ET are then calculated according to Schrader et al. (2013): 
Claus Kohfahl, et al., 2019. Monitoring and current research of groundwater resources and... Boletín Geológico y Minero, 130 (4): $661-690$

\begin{tabular}{|c|c|c|c|}
\hline Site ID/Devices & $\begin{array}{c}\text { UTM } \\
\text { Coordinates } \\
\text { X/Y }\end{array}$ & $\begin{array}{c}\text { Installed } \\
\text { depth of TDR } \\
\text { sensors (m) }\end{array}$ & $\begin{array}{l}\text { Piezometer } \\
\text { Depth }(\mathrm{m})\end{array}$ \\
\hline $\begin{array}{l}\text { Casa Control/ } \\
\text { Campbell sensors } \\
\text { CS 650, Meteo- } \\
\text { Lysimeter }\end{array}$ & $\begin{array}{l}183716 / \\
4103301\end{array}$ & $\begin{array}{l}0.3,0.6,1.2 \\
1.6,2.2,3.0\end{array}$ & - \\
\hline $\begin{array}{l}\text { Marismillas, Laguna } \\
\text { Larga/ } \\
\text { Decagon GS3 sen- } \\
\text { sors, piezometer, } \\
\text { OTT sensor }\end{array}$ & $\begin{array}{r}198626 / \\
4085145\end{array}$ & $0.20,0.50$ & 2.01 \\
\hline $\begin{array}{l}\text { Marismillas } \\
\text { /Sondeo } \\
\text { (Decagon GS3 sen- } \\
\text { sors) }\end{array}$ & $\begin{array}{r}199045 / \\
4082535\end{array}$ & $\begin{array}{c}0.45,0.85 \\
1.25,1.55\end{array}$ & 2.88 \\
\hline $\begin{array}{l}\text { Marismillas/Llanos } \\
\text { Decagon GS3 sen- } \\
\text { sors, piezometer, } \\
\text { OTT sensor, } \\
\text { Meteorological } \\
\text { Station (Davis) }\end{array}$ & $\begin{array}{r}199206 / \\
4082229\end{array}$ & $\begin{array}{c}0.17,0.47 \\
0.77\end{array}$ & 2.87 \\
\hline $\begin{array}{l}\text { Marismillas } \\
\text { Cortafuego } 7 \\
\text { Campbell sensors } \\
\text { CS650, } \\
\text { Meteorological } \\
\text { Station (Davis) }\end{array}$ & $\begin{array}{l}197507 / \\
4082719\end{array}$ & $\begin{array}{c}0.1,0.2(2 x) \\
0.3,0.8(2 x) \\
1.1,1.5,2.0 \\
(2 x), 2.3\end{array}$ & - \\
\hline $\begin{array}{l}\text { Santa Olalla P1/ } \\
\text { piezometer }\end{array}$ & $\begin{array}{l}190100 / \\
4098430\end{array}$ & - & 3.75 \\
\hline $\begin{array}{l}\text { Santa Olalla P2/ } \\
\text { Campbell sensors } \\
\text { CS650, piezometer, } \\
\text { OTT }\end{array}$ & $\begin{array}{l}190500 / \\
4097792\end{array}$ & $\begin{array}{l}0.35(2 x) \\
0.74(2 x) \\
1.25\end{array}$ & 2.47 \\
\hline $\begin{array}{l}\text { Santa Olalla P3/ } \\
\text { Campbell sensors } \\
\text { CS650, piezometer, } \\
\text { OTT }\end{array}$ & $\begin{array}{l}189901 / \\
4097657\end{array}$ & $\begin{array}{l}0.12(2 x) \\
0.25\end{array}$ & 1.62 \\
\hline $\begin{array}{l}\text { Laguna Santa Olalla } \\
1 / \text { Meteorological } \\
\text { Station (Davis) }\end{array}$ & $\begin{array}{r}190374 / \\
4098113\end{array}$ & - & $\begin{array}{l}\text { Multilevel } \\
\text { piezometer }\end{array}$ \\
\hline
\end{tabular}

Table 5. Installed devices of the monitoring network.

Tabla 5. Dispositivos instalados en la red de monitoreo.

\begin{tabular}{|c|c|c|}
\hline Measured parameter & $\begin{array}{c}\text { Time } \\
\text { interval }\end{array}$ & Site \\
\hline Soil mass lysimeter & $1 \mathrm{~min}$ & Casa Control \\
\hline $\begin{array}{l}\text { Water mass drained } \\
\text { from lysimeter }\end{array}$ & $1 \mathrm{~min}$ & Casa Control \\
\hline $\begin{array}{l}\text { Soil water tension } \\
\text { and temperature }\end{array}$ & $10 \mathrm{~min}$ & $\begin{array}{l}\text { Casa Control ( } 1.4 \mathrm{~m} \text { depth, } \\
\text { inside and outside of } \\
\text { lysimeter) }\end{array}$ \\
\hline $\begin{array}{l}\text { Stable isotopes of } \\
\text { water }\end{array}$ & 21 days & Casa Control \\
\hline Soil moisture & $10-30 \mathrm{~min}$ & $\begin{array}{l}\text { Casa Control, } \\
\text { Marismillas/Laguna Larga, } \\
\text { Marismillas /Sondeo, } \\
\text { Marismillas Llanos, } \\
\text { Cortafuego 7, Santa Olalla } \\
\text { P2, Santa Olalla P3 }\end{array}$ \\
\hline Wind direction & $10-30 \mathrm{~min}$ & $\begin{array}{l}\text { Casa Control, Marismillas } \\
\text { Llanos, Cortafuego 7, } \\
\text { Laguna Santa Olalla } 1\end{array}$ \\
\hline Wind velocity & $10-30 \mathrm{~min}$ & $\begin{array}{l}\text { Casa Control, Marismillas } \\
\text { Llanos, Cortafuego 7, } \\
\text { Laguna Santa Olalla } 1\end{array}$ \\
\hline Net radiation & $10-30 \mathrm{~min}$ & $\begin{array}{l}\text { Casa Control, Marismillas } \\
\text { Llanos, Cortafuego 7, } \\
\text { Laguna Santa Olalla } 1\end{array}$ \\
\hline Precipitation & $10-30 \mathrm{~min}$ & $\begin{array}{l}\text { Casa Control, Marismillas } \\
\text { Llanos, Cortafuego 7, } \\
\text { Laguna Santa Olalla } 1\end{array}$ \\
\hline Air humidity & $10-30 \mathrm{~min}$ & $\begin{array}{l}\text { Casa Control, Marismillas } \\
\text { Llanos, Cortafuego 7, } \\
\text { Laguna Santa Olalla } 1\end{array}$ \\
\hline $\begin{array}{l}\text { Air and soil thermal } \\
\text { profile }\end{array}$ & $10-30 \mathrm{~min}$ & $\begin{array}{l}\text { Casa Control, Marismillas } \\
\text { Llanos, Cortafuego 7, } \\
\text { Laguna Santa Olalla } 1\end{array}$ \\
\hline Soil bulk density & Once & All sites \\
\hline $\begin{array}{l}\text { Grain size distribu- } \\
\text { tion }\end{array}$ & Once & All sites \\
\hline Mineralogy & Once & All sites \\
\hline
\end{tabular}

Table 6. Installed devices of the monitoring network.

Tabla 6. Dispositivos instalados en la red de monitoreo.

$$
\begin{gathered}
\Delta \mathrm{W}=\Delta \mathrm{Wlys}+\Delta \text { wdrain } \\
\mathrm{P}=\Delta \mathrm{W} \text { if } \Delta \mathrm{W}>0 ; 0, \text { if } \Delta \mathrm{W} \leq 0 \\
\mathrm{ET}=\Delta \mathrm{W} \text { if } \Delta \mathrm{W}<0 ; 0, \text { if } \Delta \mathrm{W} \geq 0
\end{gathered}
$$

where $\Delta$ wlys $[\mathrm{kg}]$ is the mass change of the lysimeter

during each time interval which corresponds to the water storage change; $\Delta$ wldrain $[\mathrm{kg}]$ is the mass change measured in the drainage vessel.

\section{Results}

Lysimeter data are represented in Figure 18 a without previous treatment. 
a)

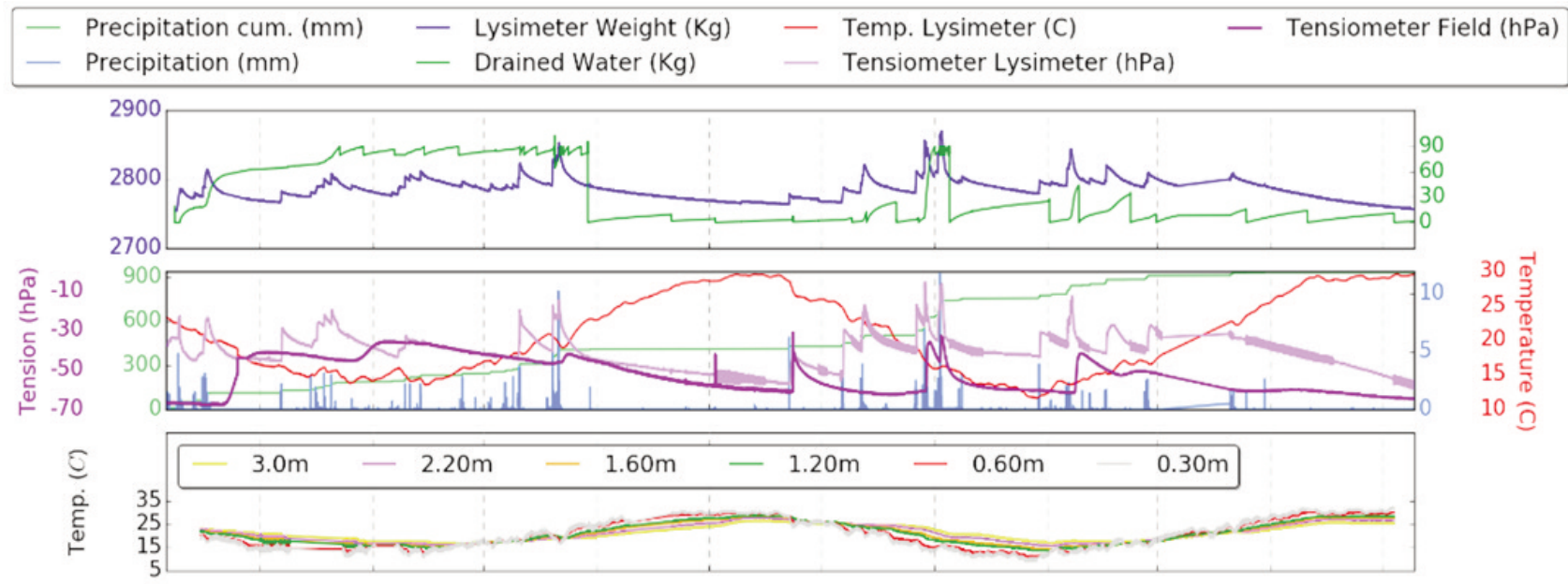

d)

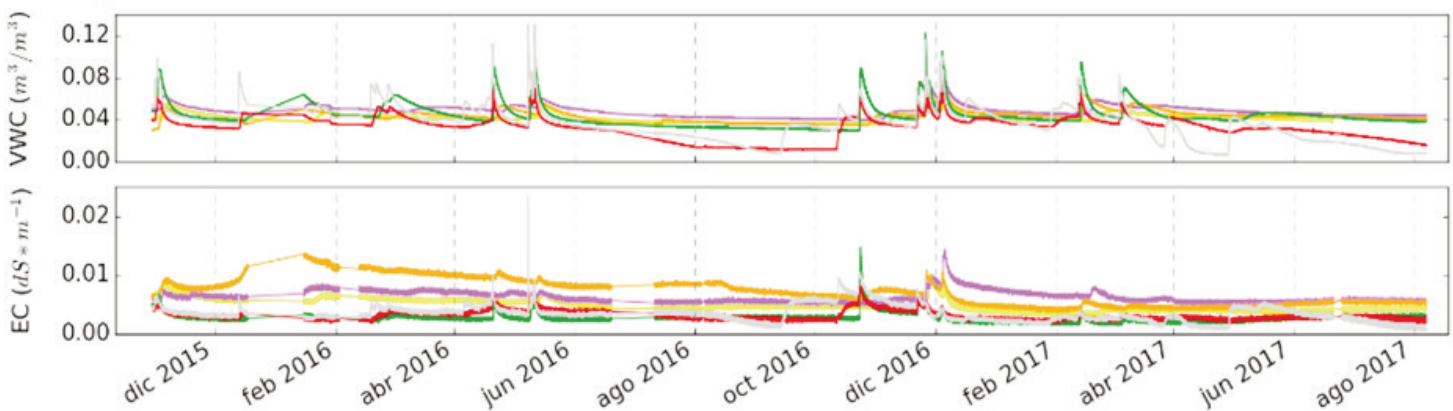

Figure 18. a) Weight of lysimeter and drainage vessel in $\mathrm{kg}$; b) $\mathrm{P}$ measured by tipping bucket rain gauge ( $\mathrm{mm}$ ) and its cumulative $\mathrm{P}$ ( $\mathrm{mm}$ ), suction measured at $1.4 \mathrm{~m}$ depth by tensiometer installed in and beside lysimeter ( $\mathrm{hPa})$, temperature from lysimeter at $1.40 \mathrm{~m}$ depth $\left({ }^{\circ} \mathrm{C}\right)$; c) Temperature profile beside the lysimeter measured by CS650 soil moisture sensors $\left({ }^{\circ} \mathrm{C}\right)$; $\mathrm{d}$ ) volume water content (VWC) measured by CS650 soil moisture sensors $\left(\mathrm{m}^{3} / \mathrm{m}^{3}\right)$; e) bulk electrical conductivity (EC) measured by CS650 soil moisture sensors (dS/m).

Figura 18. a) Peso del lisímetro y del recipiente de drenaje en $\mathrm{kg}$; b) $\mathrm{P}$ medido inclinando las cubetas del pluviómetro (mm) y su $P$ acumulada $(\mathrm{mm})$, succión medida $1.4 \mathrm{~m}$ de profundidad por un tensiómetro instalado dentro y junto al lisímetro (hPa), temperatura medida por el lisímetro a $1.40 \mathrm{~m}$ de profundidad $\left({ }^{\circ} \mathrm{C}\right)$; c) Perfil de temperaturas junto al lisímetro medido por sensores de humedad CS650 $\left({ }^{\circ} \mathrm{C}\right)$; $d$ ) contenido volumétrico de agua (VWC) medido con sensores de humedad CS650 ( $\left.\mathrm{m}^{3} / \mathrm{m}^{3}\right)$; e) conductividad eléctrica (CE) medida con sensores de humedad CS650 (dS/m).

Sudden drops in the weight of the drainage vessel corresponded to the withdrawal of water. These kinds of errors are automatically, or sometimes manually, corrected. Figure $18 \mathrm{c}$, d and e show temperature, volume water content and EC recorded by the Campbell sensors. Figure 19 shows air and soil temperature at different heights and depths.

Recorded time series of soil moisture, precipitation, temperature, and pore conductivity at 3 locations of the Marismillas site are shown in Figure 20.

The soil water bucket components measured by the lysimeter in the hydrological year 2016/2017 are compiled in Table 7.

The close agreement of measured and calculated values of the lysimeter weight increase demonstrate the reliability of the determined soil water balance components.

\section{Conclusions}

The monitoring of piezometer networks of the first subchapter show that intense agricultural groundwater extractions for irrigation have led to a general decrease of the groundwater level with regionally different degrees of impact. For the period 2016-2021, the administration in charge $(\mathrm{CHG})$ declared that four of the eight aquifers do not meet a good quantitative standard and the other 4 aquifers do not show good qualitative conditions due to elevated nitrate concentrations.

Model based studies proved the utility of the model, but actualisation requires recalibration of the model and revision of the conceptual model. Within the current research project CLIGRO, a refined loop model will be set up for the Santa Olalla site to study 

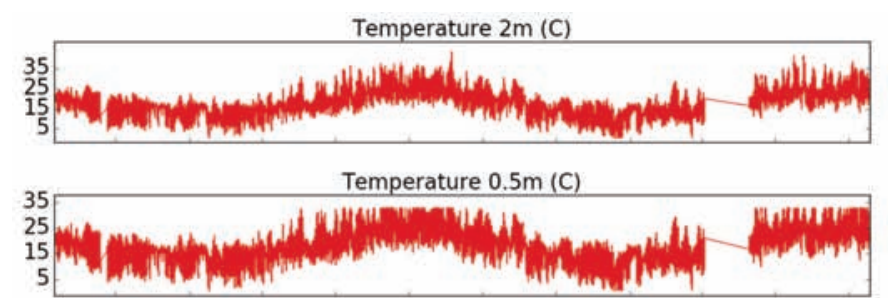

Temperature $0.05 \mathrm{~m}(\mathrm{C})$

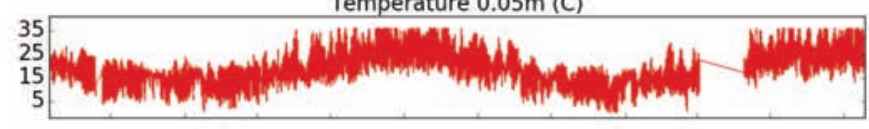

Temperature $-0.05 \mathrm{~m}(\mathrm{C})$

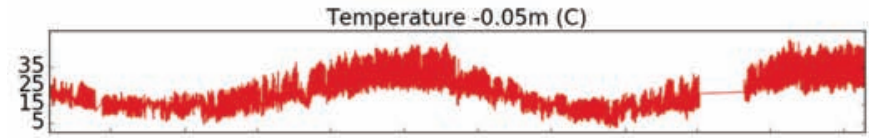

Temperature $-0.1 \mathrm{~m}(\mathrm{C})$

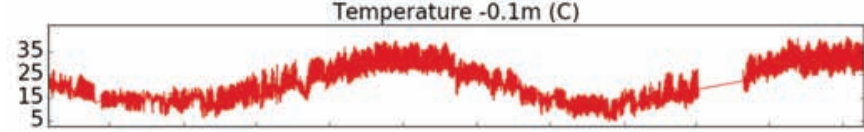

Temperature $-0.2 \mathrm{~m}(\mathrm{C})$

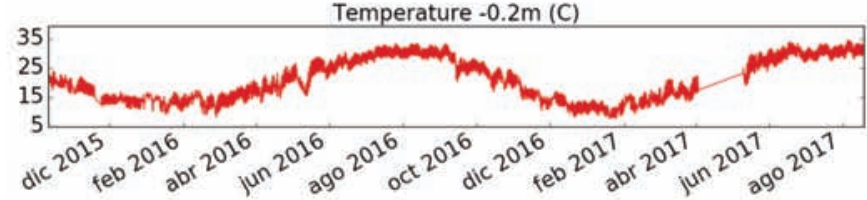

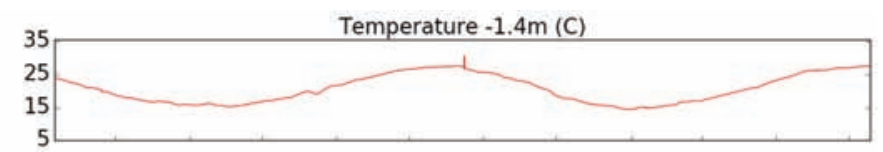

Wind speed $(\mathrm{m} / \mathrm{s})$

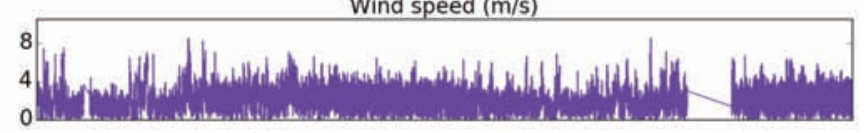

Wind direction (Degs)

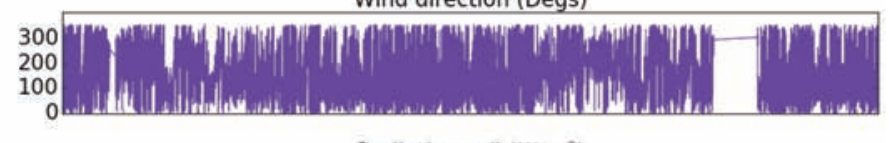

Radiation soil $\left(W / m^{2}\right)$
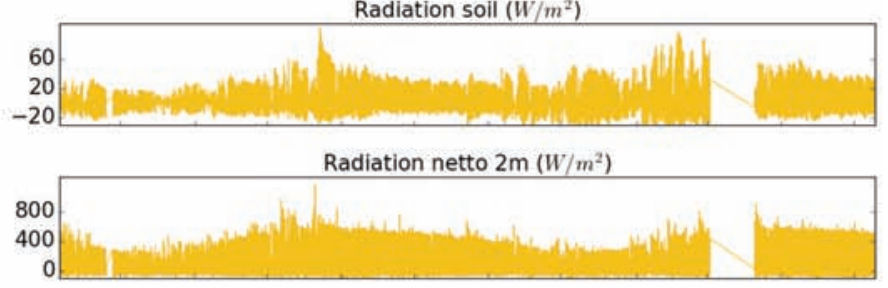

Relative humidity (\%)

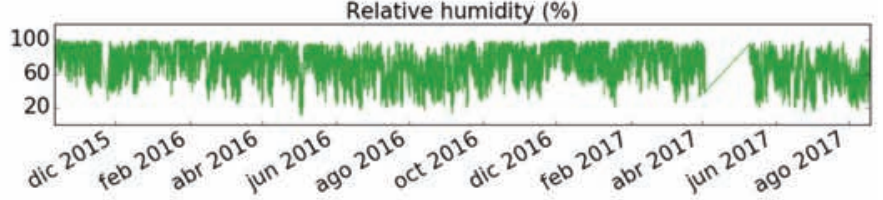

Figure 19. Temperature at the indicated depths, wind speed and direction, ground and net radiation, and air relative humidity measured every 10 minutes. Values given in $\mathrm{m}$ refer to distance from soil surface. Wind speed, wind direction, net radiation, and relative humidity, measured at 10 min intervals.

Figura 19. Temperatura medida en las profundidades indicadas, dirección y velocidad del viento, radiación terrestre y neta, y humedad relativa del aire medida cada 10 minutos. Valores dados en m medidos desde la superficie del suelo. Velocidad del viento, dirección del viento, radiación neta y humedad relativa, medidos cada 10 minutos.

groundwater- surface water interactions dependent on meteorological parameters.

Results show that in the upper part of the Eolian Unit, down to some $30-40 \mathrm{~m}$ depth, groundwater is lowly mineralized and has $\mathrm{Na}-\mathrm{Cl}$ facies. It is the result of the rainwater infiltration, slightly concentrated by evapotranspiration, and dissolution of soil $\mathrm{CO}_{2}$ and $\mathrm{Na}$ and K- feldspars, accompanied by cation exchange. In the deeper part of the Eolian Unit groundwater evolves to $\mathrm{Ca}-\mathrm{HCO}_{3}$ type because of calcite dissolution. The resulting mineralization ranges from very low to moderate. The natural composition of the groundwater changes from the unconfined areas to the confined sector under the marshes mostly by mixing with old marine water, accompanied by $\mathrm{Na} / \mathrm{Ca}-(\mathrm{Mg})$ cation exchange, sulphate reduction and calcite dissolution/precipitation, depending on the zone. The resulting salinity ranges from $1 \mathrm{mS} \mathrm{cm}^{-1}$ up to $80 \mathrm{mS} \mathrm{cm}^{-1}$. In the shallower layers $(<40 \mathrm{~m})$ of the Eolian Mantle, the natural groundwater composition is modified due to pollution with agrochemicals $\left(\mathrm{NO}_{3}\right.$,
$\mathrm{SO}_{4}$ and the trace metals $\mathrm{Co}, \mathrm{Cu}$ and $\left.\mathrm{Zn}\right)$. Isotope data rule out an origin of metallic sulphides from mining activities in the lberian Pyrite Belt. Continuous studies carried out for more than 20 years indicate that reduction processes occur in different zones of the Eolian Mantle and at different depths. However a reduction front does not exist. The knowledge generated mostly due to the accumulation of different data to perform analyses and modelling, but the last data are from 2010.

Results of the arsenic study showed that different mechanisms of mobilisation control the distribution of natural As in the Doñana National Park leading to elevated As concentrations in ground and surface water in a very limited area close to the Marismillas Palace. Elevated As concentrations in the groundwater were related to low redox values and high organic contents in the sediments, whereas high As in the surface water was controlled by high alkalinity.

Given the relevance of the Doñana aquifer and of the current and forecasted impact of groundwater 

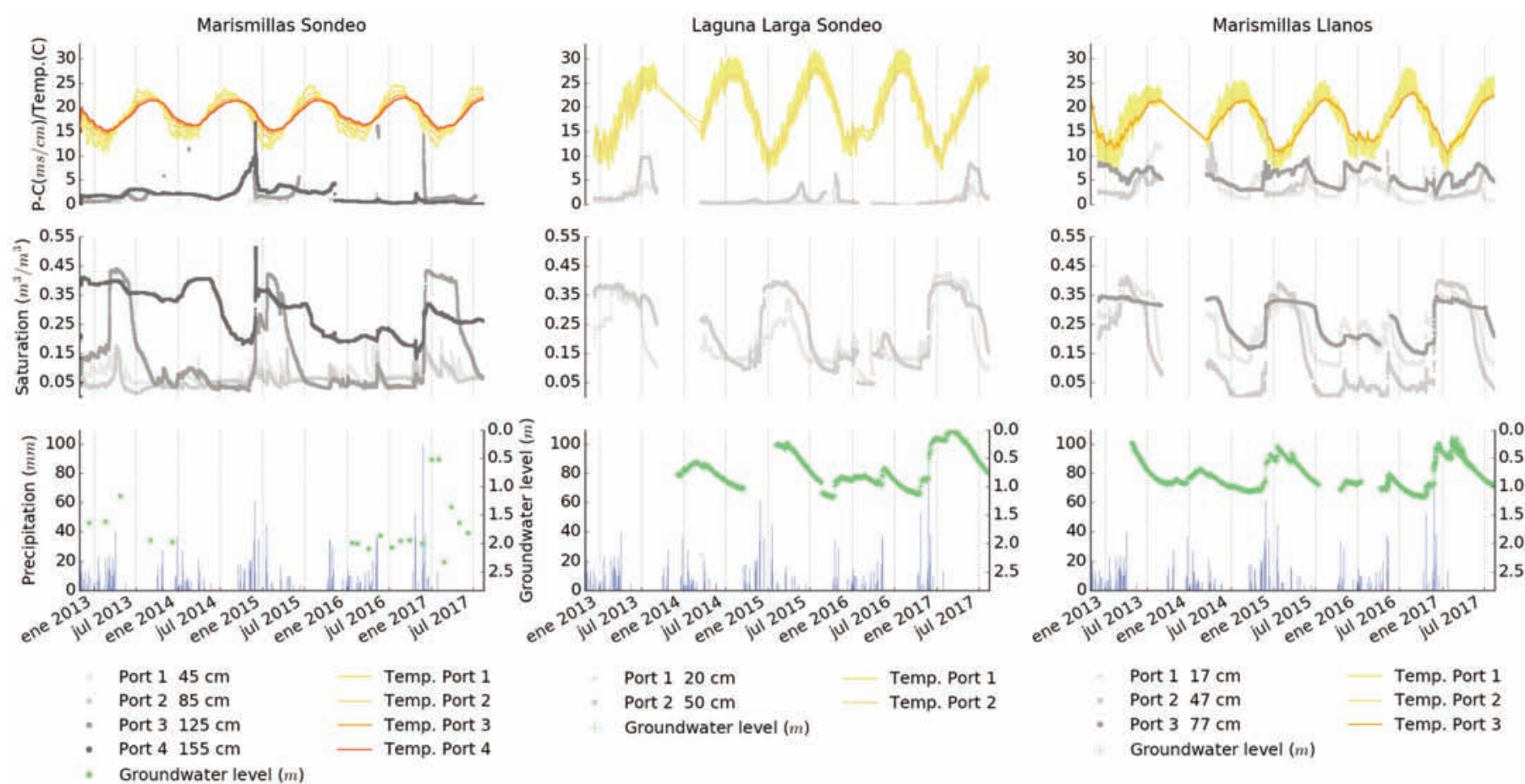

Figure 20. Soil moisture, temperature and pore conductivity at the indicated depths measured since December 2012. Daily measurements of precipitation data were provided by environmental agents from the Andalucían Regional Government (Junta de Andalucía).

Figura 20. Humedad del suelo, temperatura y conductividad de poros medidas en las profundidades indicadas desde diciembre de 2010. Medidas diarias de precipitación facilitadas por los agentes forestales de la Junta de Andalucía.

pumping and global change, it would be advisable to continue with surveys of chemical and selected isotopic analyses.

Finally, it has been shown that the installed

\begin{tabular}{|l|l|}
\hline Parameter & Volume \\
\hline Recharge & $413 \mathrm{~mm}$ \\
\hline Total precipitation (lysimeter) & $643 \mathrm{~mm}$ \\
\hline Vapour adsorption (lysimeter) & $\begin{array}{l}\text { Ranging between } 76-146 \mathrm{~mm} \\
\text { (according to measurement } \\
\text { method) }\end{array}$ \\
\hline Real evaporation (lysimeter) & $240 \mathrm{~mm}$ \\
\hline Rainfall (pluviometer) & $566 \mathrm{~mm}$ \\
\hline Water soil balance (equ. 1) & $-9.65 \mathrm{~kg}$ \\
\hline $\begin{array}{l}\text { Water soil mass change } \\
\text { obtained directly by lysimeter } \\
\text { weight difference between } \\
01.092016 \text { and 30.08.2017 }\end{array}$ & $-9.68 \mathrm{~kg}$ \\
\hline
\end{tabular}

Table 7. Annual measured parameters during the period September 2016 - August 2017.

Tabla 7. Parámetros anuales medidos durante el periodo Septiembre 2016 - Agosto 2017. groundwater recharge infrastructure is generating time series of meteorological and soil water parameters with a high accuracy and a high temporal resolution. The data obtained are currently used to (i) calibrate recharge obtained by HYDRUS1D simulations, (ii) to investigate the role of vapour adsorption and real evaporation on groundwater recharge, (iii) and (iii) to compare different methods of precipitation measurements. In addition, the recharge estimates and their dependence on the measured meteorological parameters will be used to generate prognostic recharge time series based on the temperature and precipitation data forecasted by Global Climate Models. The impact of these prognosticated changes of recharge on groundwater resources and surface water levels will be studied based on numerical groundwater flow models at different spatio temporal scales.

\section{Acknowledgements}

We are very grateful to André Peters for providing the AWAT filter. The studies of subchapter 3 were financed by the Interministerial Comission for 
Science and Technology (projects AMB-92.636; AMB-95.0372; HID.99-205; REN 01.1293), the Spanish Ministry of Economy and Competitiveness (project CGL2009-12910-CO3-03), the Spanish Ministry of the Environment (Doñana 2005), the European Commission (project EVK1-1999.0032P/2002.00527) and the International Atomic Energy Agency (CRPIsotopic Techniques for Assessment of Hydrological Processes in Wetlands, 2007-2011). The studies presented in subchapter 4 were co-financed by European Research Funds (SE Scientific Infrastructures and Techniques and Equipment 2013, IGME13-1E-2113) and by the Spanish National Plan for Scientific and Technical Research and Innovation (MICINN, CGL2016-77473-C3-1-R, CLIGRO Project). The staff involved in the activities of subchapter 4 were also funded by the National Plan of Scientific andTechnical Research 2013-2016 (PTA2014-09579-I) and the National System of Youth Guarantee (MINECO activity with reference PEJ-2014-85121) co-financed under the Youth Employment Operational Program, with financial resources from the Youth Employment Initiative (YEI) and the European Social Fund (ESF).

\section{References}

Antón-Pacheco, C. Moreno, M.T., Gumiel, J.C., Mediavilla, C. and Rebollo, A.M. 2009. Estudio de los humedales y de los usos del suelo en la comarca de Doñana y su entorno a partir de imágenes Landsat y AHS. In: La Geología e hidrogeología en la investigación de los humedales. López-Geta, J.A. and Fornés Azcolú, J.M. (eds.). Hidrogeología y Aguas Subterráneas 28, 2235249. Madrid.

Burns, D.A., Klaus, J. and McHale, M.R. 2007. Recent climate trends and implications for water resources in the Catskill Mountain region, New York, USA. Journal of Hydrology, 336, 155-170.

BOE-A-1985-16661. Ley 29/1985, de 2 de agosto, de Aguas.

BOE-A-2001-13042. Ley 10/2001, de 5 de julio, del Plan Hidrológico Nacional.

BOE-A-2013-5319. Real Decreto 355/2013, de 17 de mayo, por el que se aprueba el Plan Hidrológico de la Demarcación Hidrográfica del Guadalquivir.

BOE-A-2016-439. Real Decreto 1/2016, de 8 de enero, por el que se aprueba la revisión de los Planes Hidrológicos de las demarcaciones hidrográficas del Cantábrico Occidental, Guadalquivir, Ceuta, Melilla, Segura y Júcar, y de la parte española de las demarcaciones hidrográficas del Cantábrico Oriental, Miño-Sil, Duero, Tajo, Guadiana y Ebro.

CGS, 1994-1996. Diseño y ejecución de una red de control piezométrico en la Unidad Hidrogeológica 05.51 (Almonte-Marismas). $1^{\mathrm{a}}, 2^{\mathrm{a}}$ y $3^{\mathrm{a}}$ fase. Compañía General de Sondeos. Informe inédito.

CHG Confederación Hidrográfica del Guadalquivir, 2015.
Propuesta de proyecto de revisión del Plan Hidrológico de la Demarcación Hidrográfica del Guadalquivir. Segundo ciclo de planificación: 2015-2021. Memoria, 161 pp.

Custodio, E., Manzano, M. and Montes, C. 2008. Perspectiva general del papel y gestión de las aguas subterráneas en el Área de Doñana, Sudoeste de España. Boletín Geológico y Minero, 119 (1), 81-92.

Custodio, E., Manzano, M. and Montes, C. 2009. Las aguas subterráneas en Doñana: aspectos ecológicos y sociales. Agencia Andaluza del Agua, 243 pp.

FAO, 1970. Estudio hidrogeológico de la cuenca del Guadalquivir: informe técnico 1. AGL: SF/SPA 9. Food and Agricultural Organization. Naciones Unidas, Roma 1-115. Informe inédito.

FAO, 1972. Proyecto piloto de utilización de las aguas subterráneas para el desarrollo agrícola de la cuenca del Guadalquivir. Anteproyecto de transformación de la zona de Almonte-Marismas (margen derecha): informe técnico 1. AGL: SF/SPA 16. Food and Agricultural Organization. Naciones Unidas, Madrid, 1-534. Informe inédito.

FAO, 1975. Proyecto piloto de utilización de aguas subterráneas para el desarrollo agrícola de la cuenca del Guadalquivir. Proyecto de transformación de la zona regable Almonte-Marismas: informe técnico $7 \mathrm{AGL}$ : SF/SPA 16. Food and Agricultural Organization. Naciones Unidas, Roma: 1-157. Informe inédito.

Gómez-Rodríguez, C., Díaz-Paniagua, C. and Bustamante, J. 2011. Cartografía de lagunas temporales del Parque Nacional de Doñana. Agencia Andaluza del Agua, Consejería de Medio Ambiente, Junta de Andalucía, 56 pp.

Green, T.R., Taniguchi, M. and Kooi, H. 2007. Potential impacts of climate change and human activity on subsurface water resources. Vadose Zone Journal, 6, $531-532$.

Guardiola-Albert, C., Murillo, J.M., Martín Machuca, M., Mediavilla C. and López Geta, J.A. 2005. Modelo matemático revisado del acuífero Almonte-Marismas: aplicación a distintas hipótesis de gestión. VI Simposio del agua en Andalucía, Sevilla, 799-810.

Guardiola-Albert, C., Murillo, J.M., Mediavilla, C., Martín Machuca, M. and López Geta, J.A. 2007. Aportes de la modelación matemática a la gestión de los recursos hídricos en el entorno de Doñana. XII Congreso Internacional de Energía y Recursos Minerales, Oviedo, 434-436.

Guardiola-Albert, C., Murillo, J.M., Mediavilla C., Martín Machuca, M. and López Geta, J.A. 2008. Aportes de la modelación matemática a la gestión de los recursos hídricos subterráneos en Doñana. VII Simposio del Agua en Andalucía, Baeza, II, 833-844.

Guardiola-Albert, C., García-Bravo, N., Mediavilla, C. and Martín Machuca, M. 2009. Gestión de los recursos hídricos subterráneos en el entorno de Doñana con el apoyo del modelo matemático del acuífero Almonte-Marismas. Boletín Geológico y Minero, 120 (3), 361-376.

Guardiola-Albert, C. and Jackson, C.R. 2011. Potential Impacts of Climate Change on Groundwater Supplies to the Doñana Wetland, Spain. Wetlands, 31(5), 907-920. 
Guardiola-Albert C., Mediavilla-Laso C., Aguilera H., Fernández-Naranjo N., Ruíz Bermudo F. and GarcíaBravo N. 2016. Recurso natural o recarga en la gestión del sistema acuífero Almonte-Marismas (Doñana) según la revisión del Plan Hidrológico (2016-2021) de la Demarcación del Guadalquivir. In: Las aguas subterráneas y la planificación hidrológica. Congreso hispanoluso.

Hagg, W., Braun, L.N., Huhn, M. and Nesgaard, T.I. 2007. Modelling of hydrological response to climate change in glacierized Central Asian catchments. Journal of Hydrology, 332, 40-53.

Higueras, H. L. 2014. Estudio de la relación entre acuífero y humedales en el área Mimbrales-La Vera del Manto Eólico Litoral de Doñana, Huelva. PhD thesis. Technical University of Cartagena, Cartagena, Spain.

Hoffmann, M., Schwartengräber, R., Wessolek, G. and Peters, A. 2016. Comparison of simple rain gauge measurements with precision lysimeter data. Atmospheric Research, 174-175, 120-123.

Iglesias, M. 1999. Caracterización hidrogeoquímica del flujo del agua subterránea en El Abalario, Doñana, Huelva. $\mathrm{PhD}$ thesis. Technical University of Catalonia, Barcelona, Spain.

IGME. 1976. Informe preliminar sobre la realización y resultados del modelo matemático Almonte-Marismas. $41 \mathrm{pp}$ + anexos.

IGME. 1982. Modelo matemático bidimensional del sistema acuífero $\mathrm{n}^{\circ} 27$. Unidad Almonte-Marismas. 93 pp. + anexos.

IGME, 2009. Mejora del modelo matemático del acuífero Almonte-Marismas como apoyo a la gestión de los recursos hídricos: estimación de la recarga, modelo estocástico y actualización. Instituto Geológico y Minero de España. Informe inédito.

IPCC, 2007. Climate change 2007: the physical science basis. Contribution of Working Group I to the Fourth Assessment Report of the Intergovernmental Panel on Climate Change, Cambridge, United Kingdom.

IRYDA, 1976. Informe final de los sondeos de la zona regable de Almonte-Marismas (Huelva-Sevilla). Memoria, anejo y planos, Sevilla. 100 pp. Informe inédito.

ITGE, 1991. Realización de una campaña de sondeos de apoyo a la investigación y mejora de la base para la remodelación del modelo matemático y control del Sistema Acuífero 27, Almonte-Marismas. Empresa contratista: Ibérica de Sondeos S.A. Informe inédito.

Claus Kohfahl, Daniel Sánchez-Rodas Navarro, Jorge Armando Mendoza, Iñaki Vadillo, Elena GiménezForcada, 2016. Algae metabolism and organic carbon in sediments determining arsenic mobilisation in groundand surface water. A field study in Doñana National Park, Spain. Science of The Total Environment, Volume 544,874-882.

Ledesma Castro, A., Vázquez Suñé, E., Carrera Ramírez, J., Jaén Dupont, M. and Salvany, J.M. 1999. Calibración del modelo regional de flujo subterráneo en la zona de Aznalcóllar, España: Ajuste de las extracciones. Hidrología Subterránea. Serie Correlación Ecológica $n^{\circ}$ 13. Instituto Superior de Correlación Geológica CONI-
CET. Fac. de Cs. Naturales e Instituto Miguel Lillo, Universidad Nacional de Tucumán. A.Tineo (Ed.): 21-29.

Lozano, E. 2004. Las aguas subterráneas en los cotos de Doñana y su influencia en las lagunas. PhD thesis. Technical University of Catalonia, Barcelona, Spain.

Lozano, E., Delgado, F., Manzano, M., Custodio, E. and Coleto, C. 2005. Hydrochemical characterisation of ground and surface waters in "the Cotos" area, Doñana National Park, southwestern Spain. In: Groundwater and Human Development. E.M. Bocanegra; M.A. Hernández y E. Usunoff (eds.). International Association of Hydrogeologists, Selected Papers in Hydrogeology, 6. Balkema, Leiden. 217-231.

Lucena, C. and García E. 1978. El modelo matemático del sistema acuífero de Almonte-Marismas. Boletín Geológico y Minero, 89 (2), 43-55.

Manzano, M., Custodio, E., Mediavilla, C. and Montes, C. 2005. Effects of localized intensive aquifer exploitation on the Doñana wetlands (SW Spain). In: Groundwater Intensive Use. A. Sahuquillo, J. Capilla, L. MartínezCortina and $X$. Sánchez Vila (eds.). International Association of Hydrogeologists, Selected Papers in Hydrogeology, 7. Balkema. 209-219.

Manzano, M, Custodio, E. and Higueras, H. 2007. Groundwater and its functioning at the Doñana RAMSAR site wetlands (SW Spain): role of environmental isotopes to define the flow system. International Symposium in Advances in Isotope Hydrology and its Role in Sustainable Water Resources Management. IAEA, Viena, April 2007. STI/PUB/1310. 1, 149-160.

Manzano, M., Custodio, E., Iglesias, M. and Lozano, E. 2008. Groundwater baseline composition and geochemical controls in the Doñana aquifer system (SW Spain). In: Natural Groundwater Quality. W.M. Edmunds y P. Shand. (Eds.) Blackwell. 216-232.

Manzano, M., Custodio, E., Montes, C. and Mediavilla, C. 2009. Groundwater quality and quantity assessment through a dedicated monitoring network. The Doñana aquifer experience (SW Spain). In: Groundwater Monitoring. Philippe Quevauviller, Anne-Marie Fouillac, Johannes Grath \& Rob Ward (eds). John Wiley and Sons. 273-287.

Manzano, M., Higueras, H., Custodio, E., Juárez, I., Aravena, R., Soler, A. and Puig, R. 2011. Isotopic assessment of groundwater-wetlands dynamics, pollution sources and natural attenuation processes in a sector of the Doñana Ramsar site, SW Spain. 2011 IAHS International Congress, Melbourne, Australia.

Manzano, M., Custodio, E., Lozano, E. and Higueras, $\mathrm{H}$. 2013. Relationships between wetlands and the Doñana coastal aquifer (SW Spain). In: Groundwater and Ecosystems. L.Ribeiro, T.Y.Stigter, A.Chambel, M.T.Condesso de Melo, J.P. Monteiro and A. Medeiros (eds.). International Association of Hydrogeologists, Selected Papers on Hydrogeology, 18. Taylor \& Francis. 169-182.

Martí, R. and del Moral, JC. editors. 2002. La invernada de aves acuáticas en España. Dirección General de la Naturaleza-SEO/ BirdLife, ICONA (Organismo Autónomo Parques Nacionales), 120 pp. 
McDonald, M.G., and Harbaugh, A.W. 1988. A modular three-dimensional finite-difference ground-water flow model: U.S. Geological Survey Techniques of WaterResources Investigations, 6 (A1), 586 pp.

Mortier, F., Trigueros, E. Chapond, G., Ruiz-Celaa, C., Trac, N.Q. and del Valle Cardenete, M. 1970. Investigaciones hidrogeológicas en la cuenca del río Guadalquivir. Fondo Especial de las Naciones Unidas-FAO. Roma. 2 tomos. $146 \mathrm{pp}$.

Muñoz-Reinoso, J.C. 2001. Vegetation changes and groundwater abstraction in SW Doñana, Spain. In: Journal of Hydrology 242 (2001) 197-209.

Olías, M., Cruz-San Julián, J. and Benavente, J. 1996. Estimation of transpiration from water-table oscillations in sand dunes (Corral Largo, Doñana National Park, Spain). In: Wetlands: a multiapproach perspective, J. López-Geta, J.C. Rubio and M. Martin (eds):103-110. University of Granada, Granada. Spain.

Palancar, M. 2000. Experiencia en instrumentación y control en el acuífero de Doñana. En: Jornadas técnicas sobre aguas subterráneas y abastecimiento urbano. ITGE (2000): 167-175.

Perconig, E. 1960-62. Sur la constitution géologique de I Andalousie Occidentale, en particulier du Basin du Guadalquivir (Espagne méridionale). Bulletin de la Société Géologique de France, Livre Mém. Prof. Paul Fallot, $1^{\circ}$, 229-256.

Peters, A., Nehls, T., Schonsky, H. and Wessolek, G. 2014. Separating precipitation and evapotranspiration from noise - A new filter routine for high-resolution lysimeter data. Hydrology and Earth System Sciences, 18 (3), 1189-1198.

Rebollo, A.M., Mediavilla, C. and Díaz, A.F. 2008. Análisis de la influencia de los bombeos de Matalascañas en el complejo dunar Charco delToro-Laguna de Santa Olalla, Parque Nacional de Doñana (Huelva). En: López-Geta, J.A., Rubio, J.C. y Martín-Machuca, M. (Eds.) VII Simposio del Agua en Andalucía. IGME: 655-664.

Risbey, J.S., Hamza, K. and Marsden, J. 2007. Use of climate scenarios to aid in decision analysis for interannual water supply planning. Water Resources Management, 21, 919-932.

Rodríguez, F.J. 1998. Origen y movimiento del agua intersticial en el acuitardo arcilloso de las marismas del Guadalquivir. Tesis Doctoral. Facultad de Ciencias Geológicas. Universidad Complutense de Madrid.

Schrader F., Durner W., Fank J., Gebler S., PützT., Hannes M. and Wollschläger U. 2013. Estimating Precipitation and Actual Evapotranspiration from Precision Lysimeter Measurements. Procedia Environmental Sciences, 19, 543-552.

Scott, D.A. and Rose, P. 1996. Atlas of Anatidae populations in Africa and Western Eurasia. Wetlands International Publication, $336 \mathrm{pp}$.

Serrano, L. and Serrano, L. 1996. Influence of groundwater exploitation for urban water supply on temporary ponds from the Doñana National Park (SW Spain). Journal of Environmental Management (1996) 46, 229-238.

Siljeström, P., Clemente, L., Rodríguez, A. 2002. Clima. In: Canseco, editor. Parque Nacional de Doñana; 2002. pp. 43-56.

Trick, Th. and Custodio, E. 2004. Hydrodynamic characteristics of the western Doñana Region (area of El Abalario), Huelva, Spain. Hydrogeology Journal, 12, 321-335.

UPC. 1999. Modelo regional de flujo subterráneo del sistema acuífero Almonte-Marismas y su entorno. Informe inédito. $114 \mathrm{pp}+$ anexos.

Virgós, L., Martínez Alfaro, P.E., López Vilchez, L. and Martín Machuca, M. 1983. Estudio del funcionamiento hidrogeológico del acuífero de Almonte-Marismas (sistema $\left.\mathrm{n}^{\circ} 27\right)$ mediante un modelo digital bidimensional. III Simposio del Hidrogeología, Madrid, 343-364.

Virgós, L. and Martín Machuca, M. 1995. Modelo matemático del acuífero de Almonte-Marismas. VI Simposio de Hidrogeología, Sevilla, XIX, 639-660.

Williams, P., Biggs, J., Fox, G., Nicolet, P., and Whitefield, M. 2001. History, origins and importance of temporary ponds. Freshwater Forum, 17 (1) 7-15.

Recibido: julio 2018

Revisado: septiembre 2018

Aceptado: febrero 2019

Publicado: diciembre 2019 